Article

\title{
External Shocks in the Art Markets: How Did the Portuguese, the Spanish and the Brazilian Art Markets React to COVID-19 Global Pandemic? Data Analysis and Strategies to Overcome the Crisis
}

\author{
Adelaide Duarte ${ }^{1, *(D)}$, Ana Letícia Fialho ${ }^{2}$ and Marta Pérez-Ibáñez ${ }^{3}$ \\ 1 Institute of Art History, School of Social Sciences and Humanities, Universidade NOVA de Lisboa, \\ 1099-085 Lisbon, Portugal \\ 2 Office of the President, Coordination of Museums' Affaires, University of São Paulo, São Paulo 05508-220, \\ Brazil; analeticiafialho@gmail.com \\ 3 Independent Researcher, 28028 Madrid, Spain; martaperezib@gmail.com \\ * Correspondence: duarte.adelaide@gmail.com
}

\section{check for} updates

Citation: Duarte, Adelaide, Ana Letícia Fialho, and Marta Pérez-Ibáñez. 2021. External Shocks in the Art Markets: How Did the Portuguese, the Spanish and the Brazilian Art Markets React to COVID-19 Global Pandemic? Data Analysis and Strategies to Overcome the Crisis. Arts 10: 47. https:// doi.org/10.3390/arts10030047

Academic Editor: Elena Sidorova

Received: 31 May 2021

Accepted: 6 July 2021

Published: 15 July 2021

Publisher's Note: MDPI stays neutral with regard to jurisdictional claims in published maps and institutional affiliations.

Copyright: (c) 2021 by the authors. Licensee MDPI, Basel, Switzerland. This article is an open access article distributed under the terms and conditions of the Creative Commons Attribution (CC BY) license (https:/ / creativecommons.org/licenses/by/ $4.0 /)$.

\begin{abstract}
The spread of the COVID-19 pandemic worldwide, and the restrictions imposed by the social distance and the enforced confinement, are having an impact on the art markets globally. The aim of this article is to evaluate the impact of an external shock in the primary art market, using three countries as a case study: Portugal, Spain, and Brazil. These geographies have in common being at the margins in the art market's main art hubs. It is intended to analyze how agents are responding to the new context, according to the data gathered within the gallery sector. The methods applied in the research are a combination of surveys carried out by the authors, field-based observation, along with an academic literature review, complemented by international and national reports analysis. The study's main findings allow us to characterize the art market as a very resilient sector that energetically responded to the crisis, able to adapt and overcome challenges imposed by the new pandemic situation. Contemporary art galleries expanded digital activities, kept participating in art fairs hybrid models, continued to focus on internationalization, and pointed to the strengthening of public policies towards the sector and partnerships as key strategies to overcome the crisis.
\end{abstract}

Keywords: external shocks in the art markets; primary art market; gallerists; artists; COVID-19; Portugal; Spain; Brazil

\section{Introduction}

The spread of the COVID-19 pandemic worldwide, and the restrictions imposed by the social distance and the enforced confinement, are having an impact on the art markets globally. International reports, surveys conducted by academics and organizations, academic articles and newspapers articles claim for an overwhelming impact on the art markets and on the cultural sector in a wide-angle view, predicting the sector is among the hardest hit by the pandemic (Comité Professionnel des Galeries d'Art 2020; Art Dealers Association of America 2020; Banks 2020; Gerlis 2020; Comunian and England 2020; Michalska and Brady 2020; Neves 2020; Anonymous 2021a). The sanitary crisis evolved fast, and its effects differ according to the various cultural sectors and contexts.

The art market depends heavily on an intense global calendar of events, especially art fairs and gallery exhibitions. From March 2020 onward, the face-to-face activities were canceled, businesses dependent on travel and in-person contact were suspended, the artistic activities were paralyzed, art fairs-one of the main sales channels for art galleries-interrupted, cancelled or postponed ${ }^{1}$. Conferences, projects, exhibitions, art fairs and auctions in-presence turned into online. Services and institutions closed, schools, universities, companies, museums, libraries, galleries and alternative art spaces were also 
shut down. Citizens were confined following sanitary measures; entire cities interrupted their activities, and it is still hard to predict when they will be fully reestablished.

In this frame, the art agents were impelled to be resilient; a concept from psychology that suggests resistance to situations of crisis (Pérez-Ibañez and López-Aparicio 2018, p. 221), a capacity of adaptation to new circumstances and finding alternative models of subsistence, a reinvention for themselves and their projects (Comunian and England 2020, p. 116). The art fairs changed the face-to-face model to online, created online viewing rooms, extended their online activities, operated as marketplaces, the auction houses increased the number of online sessions, the galleries improved their websites, set up a livestream of the exhibitions and talks with curators and artists. Likewise, artists improved ways to reach audiences digitally, spreading their work on social networks, on Instagram, on Facebook and drawing attention to their ongoing projects (Banks 2020, p. 651).

In this article, we intend to discuss how art markets in Portugal, Spain and Brazil are responding to this external shock. We will analyze the agents' resilience through the evaluation of the impact of the pandemic in economic terms (total revenue, export, employment) as well as in operational and relational terms. Furthermore, we will identify the main changes in the art market activities-sales, exports, exhibitions, art fairs and digital activities-and the most deployed strategies to overcome the crisis, inquiring if some of them are common in the three countries.

The art markets in Portugal, Spain and Brazil have had uneven development flow and economically fragile health in the last 15 years. Before the COVID-19 health crisis, Portugal was pointed as having one of the lowest levels of cultural practices among the population, in comparison with the countries of the European Union, a position that worsened with the aftermath of the previous 2008 global financial crisis (Neves 2020, p. 90). Brazil, on the contrary, had consistent growth of its art markets for about a decade (2005-2015), showing a slowdown in its pace of development from 2015 inwards, related to the national economic reverses, while the process of internationalization of art markets players continued steadily (Fialho 2019, p. 20). In Spain, the 2008 crisis caused the closure of numerous galleries but also triggered the birth of new, more global gallery models aimed at capturing a different way of collecting (Pérez-Ibáñez 2020, p. 176).

These three countries, with their own specificities on scale, economy, politics, history and culture, have in common being at the margins in the art markets field ${ }^{2}$. Although academic literature has been contributing to the knowledge about the complex performance of art markets internationally (Quemin 2013b; Velthuis and Curioni 2015; Zarobell 2017; Robertson 2018), it is still difficult to find theoretical contributions concerning markets outside the dominant axes, as these three countries exemplify. Moreover, the geographical proximity between Portugal and Spain, and its historical relationship, make the Iberian Peninsula a common market for buyers and collectors $^{3}$; together, they are a privileged gate for Brazilians to access the European art market. Brazil keeps close ties with both countries in terms of cultural exchanges and cooperation: Spain is a relevant destination of sales made by Brazilian galleries, while Portugal is the residency of several Brazilian artists and curators and a frequent destination of contemporary art players initiatives ${ }^{4}$. Another reason that motivated this joint paper is pragmatic: the authors belong to a cluster, "Art Market and Collecting," that hosts the research group TIAMSA subcommittee "Art Market and Collecting: Portugal, Spain and Brazil," whose purpose is to promote cooperation and data sharing among its members ${ }^{5}$. These three countries have indeed different art market scenarios, but our goal is not to forge similarities but to identify points of convergence as well as differences between these markets with strong historical and cultural ties.

The theoretical literature on the art market's performance in these regions is not extensive and does not draw attention on an international level, but there are recent contributions to its knowledge that we would like to underline. Duarte analyze the mechanisms by which the primary art market has been activated, and states for a rise in the Portuguese primary art market since the turn of the new millennium, particularly in the Lisbon art scene, due to the efforts in conjunction of private initiatives, namely the contemporary art gallerists and 
the contemporary art collectors (Duarte 2020). Afonso and Fernandes (2019) present the Portuguese art market's main features, underlining its local scope, or domestic dimension, in the frame of the history and of the trends of the art markets globally. However, in the Portuguese context, recent newspapers articles highlight the economic impact of the COVID-19 on markets, pointing out the predictable difficulties that the sector is going through or the increase in the precarity among artists (Anonymous 2020a, 2020b). Additionally, reports give inputs on how the cultural sector is reacting to the crisis (Neves 2020). In Spain, Pérez-Ibañez conducted a survey, analyzing how the artists are dealing with the crisis, bringing inputs to the discussion, and proposing alternatives to the mainstream functioning of the art system. Regarding the Brazilian situation, Fialho draws attention to the challenges faced by the cultural field since the beginning of the pandemic, pointing out the importance of public policies and investment to prevent a possible collapse in the sector (Fialho 2020). An extensive report on cultural policy and the impact of COVID-19 on the cultural sector showed how companies, workers, public investment and international trade related to different sectors behaved throughout 2020 (Observatório do Itaú Cultural 2020). A specific survey about the impact of the pandemic on the gallery sector in Argentina, Brazil, Chile and Colombia was conducted by Esmanhotto and Fialho, showing that, in comparison to many other cultural sectors, the art market in Brazil was quite resilient by adapting and overcoming challenges imposed by the new context (Esmanhotto and Fialho 2020).

It is our purpose to analyze the current state of the art markets in Portugal, Spain and Brazil to understand the determinants of their resilience and to bring insightful information about the gallery sector and the strategies of art market agents to overcome the crisis. We also intend to contribute to the widening of the art markets studies' field by bringing into light field-based information about three countries that are usually not well represented in international art markets literature neither art market reports, often focused on the high end of the art markets, in terms of turnover and market share. Therefore, the relevance of this case study is also to bring an analysis of the current situation and the tendencies observed in art markets located outside the main art hubs, suggesting that there are specificities and new dynamics that are interesting to consider in a broader discussion about the development of art markets in the coming years.

\section{Materials and Methods}

In this section, we will explain the methodology used and the materials employed in the research. First, we have analyzed the available literature on the subject. The pandemic impact on the art market is an ongoing process, and the academic literature about this phenomenon is still scarce; therefore, we consulted reports published about the impact COVID-19 had on the art markets, both national and international (Fialho and Esmanhotto, McAndrew, Neves, Comité Professionnel des Galeries d'Art 2020; Art Dealers Association of America 2020), as well as the specialized press (The Art Newspaper, Art Review, Artsy, Wallpaper, Wired, Contemporânea, Expresso, Público, Observador, Umbigo Magazine, Select, Arte!Brasileiros). The secondary sources were discussed between the authors and confronted with primary data gathered through field research (surveys, fieldbased observation, semi-structured interviews and informal conversations with art players, artists, curators and gallerists about the topic, given the authors' familiarity with the 'art world' of the respective countries). The whole research and analysis were informed by relevant theoretical contributions to the art market studies.

The research brings up primary data collected by authors in the field, complemented by information from secondary sources, all together analyzed with the support of theoretical references. The data analyzed in Section 3, and its subsections, was collected in different periods in the three countries, between April 2020 and May 2021, and the research focus was the primary market. In terms of the definition of the population surveyed, we may classify the group of galleries as "structures with a commercial purpose and a physical space organizing exhibition of works" (Quemin 2020, p. 346). This group included gal- 
leries who work with most living artists, a category that is understood here as artists with specific training (Fine Arts schools and arts academy), using various mediums (painting, photography, installation, sculpture, multiples) and recognized by peers and agents from the milieu (Becker [1982] 2010) 6 . Plus, the galleries' reach may be local, national, regional or international, and they participate in contemporary art fairs ${ }^{7}$ and have maintained activity during the years under analysis (2019-2021).

Concerning Portugal, data is coming from an anonymous survey launched to the Portuguese commercial art galleries between 22 April and 7 May 2021 through a google forms platform. In terms of the sample gathered, 70 active galleries were identified, using sources, such as the galleries' websites, the Mapa das Arts, a map of Lisbon contemporary $\operatorname{art}^{8}$ and the author's knowledge of the field. The gallery contacts were validated by telephone (28-30 April and $3 \mathrm{May})^{9}$, and the questionnaire was sent by email. If we compare the numbers we collected with the official numbers from the National Institute of Statistics (which identifies 56 galleries in the country, Estatísticas da Cultura, INE 2019, p. 131), we realize that the official numbers need updating ${ }^{10}$. The questionnaire was organized in different sections to further understand how the Portuguese primary art market is reacting to the pandemic crisis. The questions are generally closed answer and sections are as follows: (1) characterization of the business main area of expertise, (2) the gallery staff (number of employees), (3) the artists, (4) the sales (annual turnover and artworks transacted), (5) the buyers and collectors, (6) the art fairs, (7) the gallery exhibition activity, (8) the crisis impact: strategies to overcome it. Analysis was conducted with aggregate data.

The information from the Spanish art market comes from various sources: the 2020 Cultural Statistics Yearbook published by the Ministry of Culture has been one of the sources, but above all, we have focused on the data collected by the reports issued by two professionals associations, the Institute of Contemporary Art (IAC) and the Consortium of Contemporary Art Galleries, the largest association of galleries in Spain, with data provided by the associated galleries. The Consortium and the galleries it represents are members and interlocutors of FEAGA (Federation of European Art Galleries Association) with the Spanish galleries. Besides, together with the IAC and four other professional associations, the Consortium is part of the Sectorial Table of Contemporary Art, an open platform, inclusive and participatory, that brings together and represents all groups involved in the development of Contemporary Art. The dialogue that the Consortium has maintained with its represented galleries and the collection of data during the pandemic has been crucial to understanding the reality of the sector from the primary source.

Data from Brazil was also gathered through surveys, combined with interviews and conversations with art market players. The first survey was conducted in September/October 2020, and some data were updated between January and March 2021. In total, 80 art market players were contacted, and 52 participated in the research. The universe of respondents is composed mostly of galleries that operate primarily in the primary art market and that are linked to the Association of Brazilian Contemporary Art Galleries (ABACT) but not exclusively, we also had responses from a few participants of the secondary market, art fairs and digital sales platforms. All together, they represent the most professionalized and internationalized segment of the Brazilian art market. The main issues addressed were related to the economic and structural impact of the pandemic on the markets: sales results and exports, employment, artists representation, management, digital strategies, participation in art fairs, and the prognosis of companies for the coming months. The first analysis of results was published in December 2020 (Esmanhotto and Fialho 2020). Therefore, for this paper, we choose to explore some qualitative aspects we believe deserve further discussion concerning the way the market is functioning and the changes detected in relational dynamics among the players. 


\section{The Health of the Art Markets. Three Countries under Analysis. Findings}

\subsection{Portugal: What Is the Extent of the Impact of COVID-19 in the Art Markets Sector?}

The beginning of the pandemic in Portugal was delayed in comparison with some European countries, Spain, France or Italy, but the declaration of a state of emergency happened at a relatively early stage (on $19 \mathrm{March}^{11}$ ) (St. Aubyn 2020, p. 43). Following the general lockdown in the art markets sector, its impact represented a challenge for the agents involved. Observador, a Portuguese daily newspaper, noticed a "high damage" in the sector, indicating the cancellation and the postponing of the international art fairs and consequently the drop in sales (Anonymous 2020b).

In this section, we will analyze the performance of the Portuguese commercial art galleries during the 2020 COVID-19 pandemic crisis, comparing its results with the previous year of 2019 and highlighting the expectations those agents have towards the future. The data of our sample is 46 answers, from 70 sent, collected from a survey sent to gallerists through the google forms platform, as we previously mentioned. We had a very good response, with a participation rate of $66 \%$. The analysis follows the steps as shown in the questionnaire: (1) the characterization of the gallery area of expertise; (2) the gallery staff (number of employees); (3) the number of artists that galleries represent; (4) the sales (annual turnover and artworks transacted); (5) the buyers and collectors; (6) the art fairs; (7) the gallery exhibition activities; (8) the crisis impact: strategies to overcome it. This last point, concerning the measures the galleries used to overcome cancelled in-presence art fairs and the changing priorities for the sector in coming years, will be analyzed in the next subsection of this article (Section 3.1.1).

The set of galleries surveyed have a scope of action mostly in the contemporary art field, and the sample showed the primary art market as the main area of expertise. Only three art galleries had business also in the secondary art market. Their geographic location is predominantly in Lisbon with 31 answers, followed by the city of Porto with 8 answers. In the rest of the country, its representativeness is residual, with one gallery in each city ${ }^{12}$.

Data shows that the Portuguese gallery tissue is experienced, Figure $1^{13}$, with a significant $56.6 \%$ of them running the business for more than 16 years, and $26.1 \%$ having activity for more than 25 years. At the same time, data shows a relevant percentage of $26.1 \%$ of galleries younger than 5 years, meaning that the tissue gallery is growing and refreshing the art scene, particularly in Lisbon, with new projects and challenging perspectives (Duarte 2020). Concerning the gallery space, $50 \%$ has its own space. The other $50 \%$ of gallerists rented space, and between those, just for one gallery, the fixed costs represent plus than $50 \%$ in the business (the higher percentage of the inquiries, the rented spaces represent an estimated value of $11-20 \%$ of its fixed costs). Data shows for a small percentage that probably will have its financial difficulties increased from the rented space.
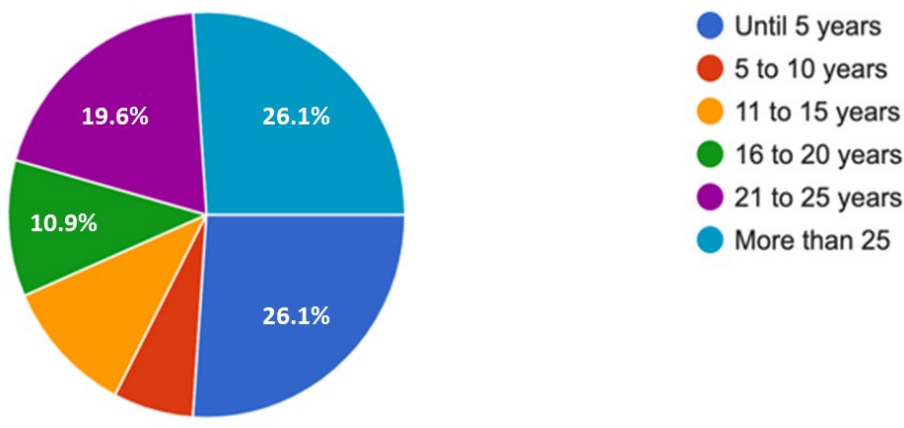

Figure 1. Gallery ages. Data source: Survey conducted by author.

The gallery's number of employees (Figure 2) is situated between 'one and five' in 2019 and 2020, and it is estimated to be equal in 2021. In these years, reducing employees was not an option. Only three galleries reveal a bigger number of employees, between 'six and ten,' meaning that Portuguese art galleries have mainly a familiar profile business ${ }^{14}$. 
These features of a mainly familiar profile of the Portuguese art galleries were confirmed by field research of the author. Their wages were kept at an estimated percentage of $91.3 \%$. Data shows that only four galleries have reduced wages to their employees. In total, 33 galleries $(71.7 \%)$ applied to the Lay-off, an extraordinary measure the Government launched to support the maintenance of employment contracts and to pay wages if the company was totally or partially closed within the scope of COVID- $19^{15}$. Still, in the field of the financial health of the business, data showed that a percentage of $84.8 \%$ had not accessed any loans or external credit to keep their business running (a percentage that corresponds to 39 galleries, in 46 answers).

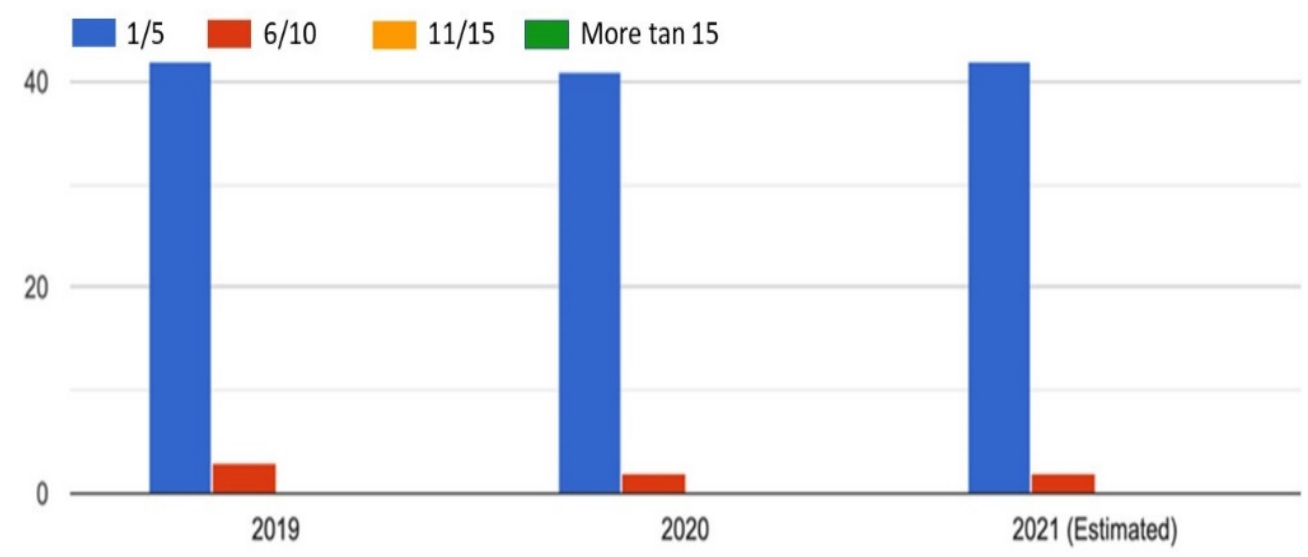

Figure 2. The number of gallery employees. Data source: Survey conducted by author.

Concerning the number of artists, an expressive number (44 answers, 95.7\%) denied having reduced the number of artists represented. Data showed a slight change in categories: just one gallery from Porto, with rented space and 'more than $25^{\prime}$ years running the business, stated to have reduced artists from 'more than 20 ' to ' $16-20^{\prime}$ artists. On the contrary, four galleries have augmented the number of artists' representation. In total, 36 galleries maintained the number of artists with whom they worked.

In terms of total revenue by segmentation value (Figure 3) and taking in mind that data showed no change in the artwork's prices during the pandemic crisis (40 answers, $88.9 \%$ ), during the years under analysis, the galleries performance reports a global decrease from figures between a center estimate value of EUR15.200 (2019, 39 answers) to EUR 11.925k (2020, 38 answers) and EUR 13.300k (estimated 2021, 37 answers) ${ }^{16}$. These totals do not include one gallery with an income bigger than EUR 5.000k per year; we may include this value in a low-value estimate, but not in a high or a center estimate because the survey only states the category 'bigger than EUR 5.000k'.
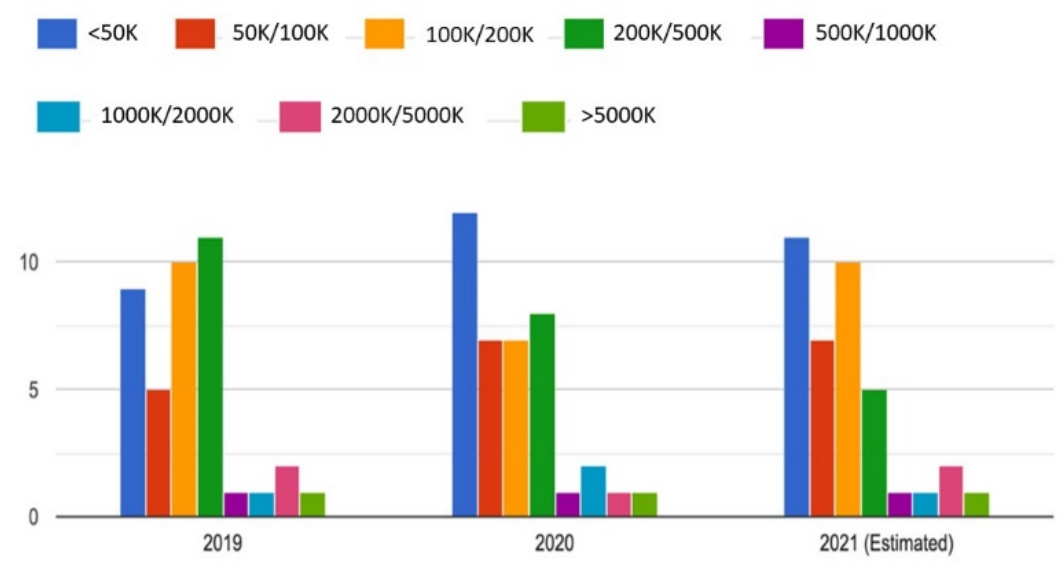

Figure 3. The total revenue by segmentation value. Data source: Survey conducted by author. 
According to data, it is observed a drop in sales in 19.4\% between 2019 and 2020, meaning the Portuguese percentage is inferior to the international figures ${ }^{17}$; and only a drop of $7.9 \%$ between 2019 and $2021^{18}$.

However, as we can see in Table 1, fluctuations in revenue shows 21 galleries keeping equal total revenue (referring to previous year), between 2019-2020 and 2020-estimated 2021. In total, eleven galleries decreased and maintained their revenue (referring to previous year), six in the first year, five in the second. Moreover, two galleries rose in the second year (referring to previous year), and three recovered losses from the first year.

Table 1. Fluctuations in revenue between 2019-2020 and 2020-estimated 2021.

\begin{tabular}{cccccc}
\hline$==$ & $\downarrow=$ & $=\downarrow$ & $=\uparrow$ & $\downarrow \uparrow$ & NA \\
\hline 21 & 6 & 5 & 2 & 3 & 9 \\
\hline
\end{tabular}

= Same category of revenue referring to the previous year; $\downarrow$ Decrease of revenue referring to the previous year; $\uparrow$ Increase of revenue referring to the previous year; NA: No answer; Data source: Survey conducted by author.

Regarding the figures reached on 'online sales,' Figure 4, data shows a higher incidence of business at lower values, with a growing trend, between a center estimate value of EUR 4.975k (2019), to EUR 5.375k (2020), and EUR 5.800k in an estimated 2021, in line with the international results for this segment of the art markets (McAndrew 2021, p. 21) ${ }^{19}$. Data shows an increase of $8 \%$ in online sales in 2020, but significant growth of $16.6 \%$ between 2019 and the estimated 2021.

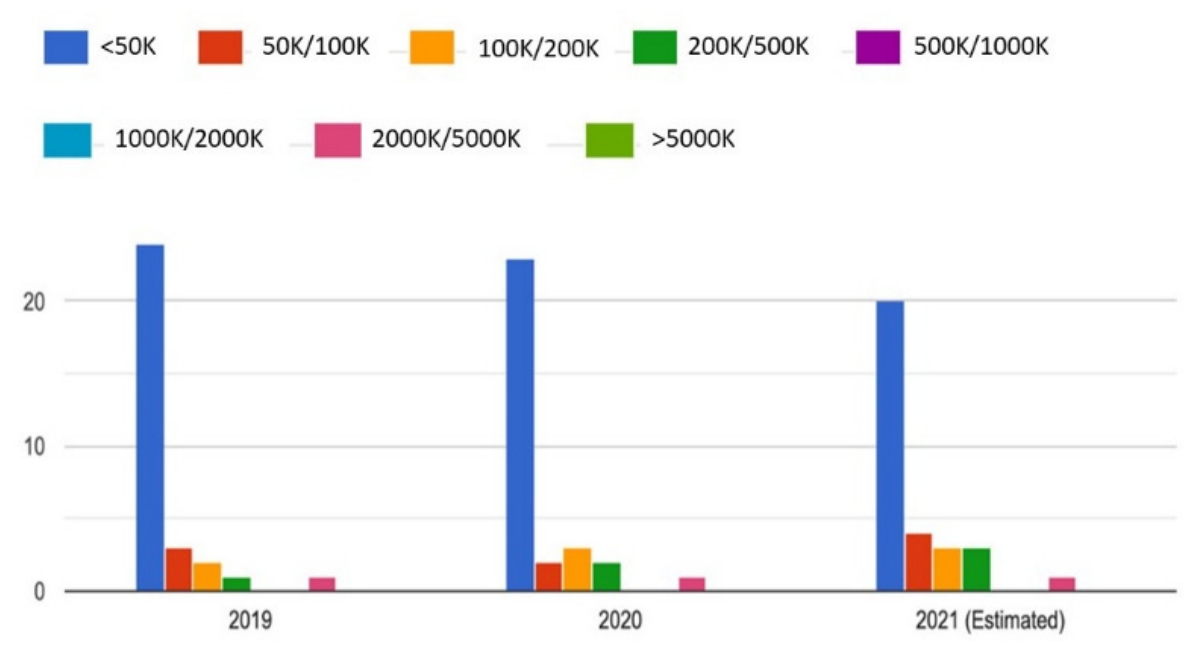

Figure 4. Online sales. Data source: Survey conducted by author.

Who are the buyers? According to data, the main buyer's type (Figure 5) is the private collector (with 44 answers in 2019 and 2020). This category is followed by the private institutions, art market professionals (dealers), local museums, national museums and international museums, although with a low number, reinforcing the idea that the art markets are mostly dependent on private hands (Duarte 2020).

The Ministry of Culture was among galleries' buyers, who answered in a percentage of $52.2 \%$ (24 answers). However, data shows low revenues from acquisitions from the Ministry of Culture: until EUR 5k (4 galleries), between EUR 5-10k (6), EUR 10-15k (2), EUR 15-20k (4), EUR 25-30k (3), and more than EUR 30k (just three galleries). The Municipality of Lisbon was also among institutional buyers, in a smaller percentage of $23.8 \%$ (10 galleries). 


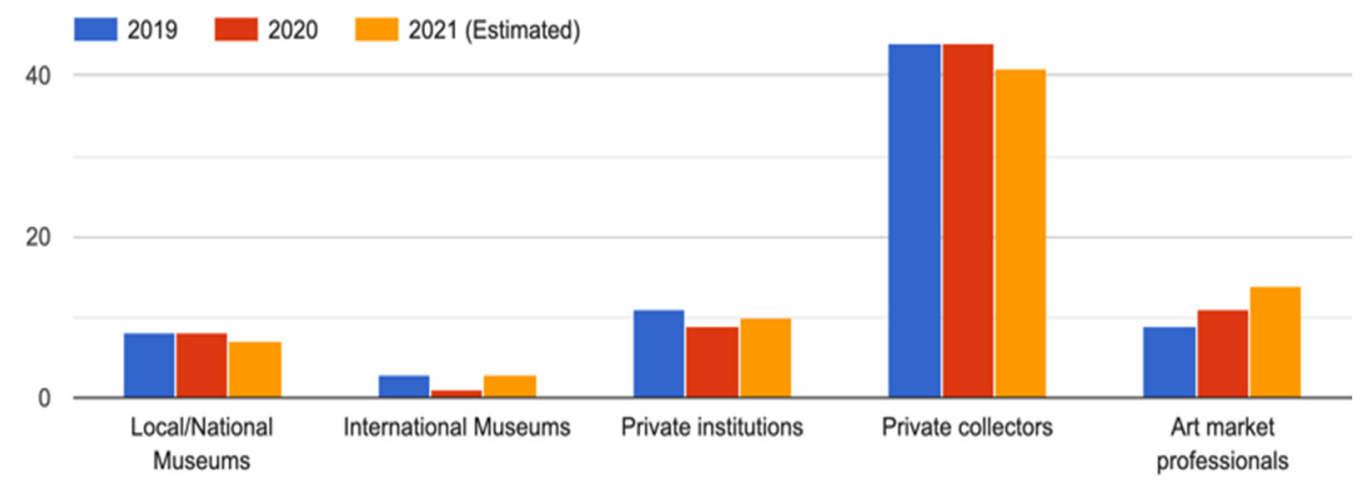

Figure 5. The main buyer's type. Data source: Survey conducted by author.

Concerning in-presence art fairs, data shows that 33 galleries participated in between 'one and five' in 2019, a number that tends to maintain in 2020 and in the estimated 2021. Only five galleries participated in 'six to ten' art fairs in 2019 but none in 2020, and only two are estimated in 2021. The number of online art fairs increased from 2019 to 2020, from 18 to 30 participations. Its non-attendance resulted in a decrease in revenue (admitted by 16 galleries) and in a positive balance due to the non-payment of attendance fees (registered by 6 galleries).

The exhibition plans were drastically reduced with the lockdown, admitted by $97.8 \%$ of the galleries (only one gallery stated for no changes). The lowest category, with only 'one to five exhibitions' per year, had a higher number of responses in 2020, and the same value is predictable in 2021. Along with the reduced exhibitions numbers, the art galleries noticed a strong reduction in public attendance, while safety protocols in place, in a percentage of $87 \%$ (40 galleries).

\subsubsection{Strategies to Overcome the Crisis and Changing Priorities for the Sector}

The Lisbon-based Bruno Múrias Gallery has recently come from Frieze New York, where Múrias had participated in the 2021 edition (5-9 May). He presented a solo project from Henrique Pavão in the Frame section devoted to emergent artists and to younger galleries that have been working for less than ten years (Keh 2021; Sutton 2021). To be part of the first in-person big event post-pandemic crisis, Múrias had to leave the Schengen space for 14 days, staying in Dubai, to get permission into New York and to participate in the art fair due to international travel restrictions between Europe and the USA. The gallerist found the art market in good shape as he reported relevant sales ${ }^{20}$. The reopening of large-scale events brings to discussion changes predicted by scholars and critics concerning the scale of the art fairs, its heavy calendar and their high costs, and probably will come from inside of the art system the need to boost the scaled-down boutique art fairs (Saltz 2021; Duarte 2020).

In this subsection, it is our purpose to analyze the strategies the galleries used to react to the crisis impact. We will underline the changing priorities agents believe are useful to overcome the pandemic crisis, using data from the survey, and thus observed the need for public policies to further encourage the sector. Finally, and to complement the analysis, we will look at artists, seeing how they are reacting to the pandemic, based on field research.

"Agents need to think as one and work together": this anonymous statement, obtained in the survey, systematizes the need the sector feels for corporatism and to demand policies of convenience to boost business. In this regard, it would be useful to revitalize the association of art galleries or to relaunch another one capable of aggregating the sector around a common cause and use it as a mediation tool in defense of members' interest $\mathrm{t}^{21}$. It is in the interest of gallerists to promote a stronger recognition in society of the role played by the sector in the economic and the cultural life of the country. As stated in the survey, it is useful to reinforce a deeper education at school in arts and culture, in its articulation with the art world (Becker [1982] 2010) and the art markets system, stimulating 
curiosity, taste, and criticism on contemporary art, accustom students with the gallery milieu, reaching new audiences. It is also underlined the need to increment business with specific measures (as its characterization showed a sector predominantly with small size companies): tax reduces (VAT) from the current $23 \%$ to stimulate purchases; a regular investment in acquisitions from the State, increasing museum collections and stimulating private collectors, and financially support the participation at international art fairs (as it contributes to the internationalization of its artists).

As the market is much dependent on art fairs events, concerning participation from the Portuguese gallery sector in the pandemic period, it is noticed a decrease in the number of in-person participation, aligned with the global trend. Most of the art fairs were cancelled, postponed, or transformed into online versions. However, the ARCOmadrid, the most relevant art fair for Portuguese galleries, held in February, kept its full program, although agents already discussed the arrival of the pandemic in its corridors. In October 2020, the Drawing Room Lisbon opened a hybrid format, both in-presence and online, allowing business for 20 galleries, four of which from outside the country ${ }^{22}$. Besides Drawing Room, Lisbon did not have another art fair in 2020 (ARCOlisboa was an online edition, and JustLx was postponed $)^{23}$. Gallerists agree about the relevance of maintaining arts fairs in-person and stimulating the Government to increase purchases during the events, helping artists and thus gallerists who support and invest in their exhibitions. Still in this field, Portuguese gallerists increase their presence in online events, as we mentioned before.

Data showed that the galleries used the lockdown to work on an energetic presence on digital and social networks: Facebook, Instagram, online platforms (Artsy), WhatsApp, weekly newsletters and mailing clients regularly. Galleries improved their virtual communication and websites: created viewing rooms, short videos, talks with artists and curators streamed online. The aim was to gain visibility, reach new clients and collectors, stimulate online sales and diversify sales channels. This strategy was well succeeded, considering the increasing trend of the income revenues, but we are convinced that it could be properly explored and improved in the coming years because the higher incidence of digital business is at the lowest category.

A key priority to recover and further develop the art market sector pointed by gallerists is strengthening public policies. The systematic artworks purchase to swell the public collections will be a welcome step, gallerists claim. Just before the pandemic, the Portuguese Ministry of Culture reinforced the amount for artworks acquisitions, restoring a program of acquisitions, whose total amount went from EUR 300k to 500k in 2020, with the engagement of an increase until EUR 650k in 2021 (Cardoso 2018; Salema 2020). Agents saw this decision as a commitment sign but insufficient. We recall that $47.8 \%$ of the surveyed galleries did not have any acquisition from this program. Besides, the Government did not award any budget for acquisitions to the Museu Nacional de Arte Contemporânea, in Lisbon (National Museum of Contemporary Art), the museum devoted to modern and contemporary art under his tutelage. On the contrary, the aim, as it has been recently decreed, is to create a contemporary art network with several centers throughout the country ${ }^{24}$. Therefore, what apparently is a good measure, is actually insufficient and seems poorly structured. Still, at an institutional level, the Lisbon municipality reinforced its contemporary art acquisitions, keeping the agreement with IFEMA to stimulate purchases during the ARCOlisboa. Although ARCOlisboa 2020 was an online edition, the municipality kept purchases, thus helping artists and galleries in the pandemic period ${ }^{25}$. Those purchases wanted to stimulate the art market and the collecting practices, but the criteria for the choice of artists is not clear neither the acquisitions policy. These measures for the acquisitions of artworks do not appear to be structural but rather punctual, and public collections seem to be unarticulated in terms of new incorporations.

The survey we launched refers to artists indirectly, focusing on the gallery business and the dissemination of their work among collectors and potential customers. Field-based observation shows that artists who have representation in galleries are more protected from external shock situations, as COVID-19, and those who have not, have seen an 
increasing difficulty on work conditions, exhibitions postponed, projects cancelled, and lower incomes (Anonymous 2020b; Neves et al. 2021a). Artists generally work informally, without a contract, with an irregular and precarious activity that does not guarantee the sector autonomy (Neves et al. 2021a, p. 1) ${ }^{26}$. To further understand this external shock, Sara and André launched an Inquérito a 263 artistas (Survey to 263 artists), whose results were published in a special issue of the Contemporânea review ${ }^{27}$. The authors gathered a set of testimonies from artists of different generations whose perspective is focused on how artists perceived the crisis, the strength of resilience and methods to overcome it. Their answers, however, look like an artistic project rather than a sociological analysis of the COVID-19 impact on their lives and work. It configures, nevertheless, conceptual material to discuss deeper the coming years through their lenses and the desire for change in the art system for a more inclusive system. Plus, it shows a growing sense of an artistic community.

The sense of community observed among artists helps us understand the creation of the Associação dos Artistas Visuais em Portugal (AAVP) (Association of Visual Artists in Portugal) on 17 September 2020. Its purpose is to mediate its interests and to discuss artists concerns with tutelage (Anonymous 2021f). The first results can be seen in its contribution to the debate about the status of the artist. The non-existent tributary career is an obstacle to obtain financial support from the State, so this discussion is an important legal step to allow artists to have social protection ${ }^{28}$.

Furthermore, we will underline a platform for artists, the SOS Arte PT, launched online at the beginning of April 2020. It aimed to foster resilience amidst artists and to minimize predictably high effects on their incomes. This platform evolved to an association, and one year later (May 2020), organized the first art fair edition. The peculiarity of this initiative is its statement, as it advocates to be a new paradigm for art fairs, i.e., not including taxes, neither intermediaries between artists nor buyers. Named Mercado P'Arte (Market for Art) (Figure 6), it gathered around 30 artists in a garage, claiming to be successful in facing the economic crisis $^{29}$. It is too early to evaluate its performance but is a sign that the system may change due to the joint action of artists and other market players or that it will find alternative measures to the mainstream system.

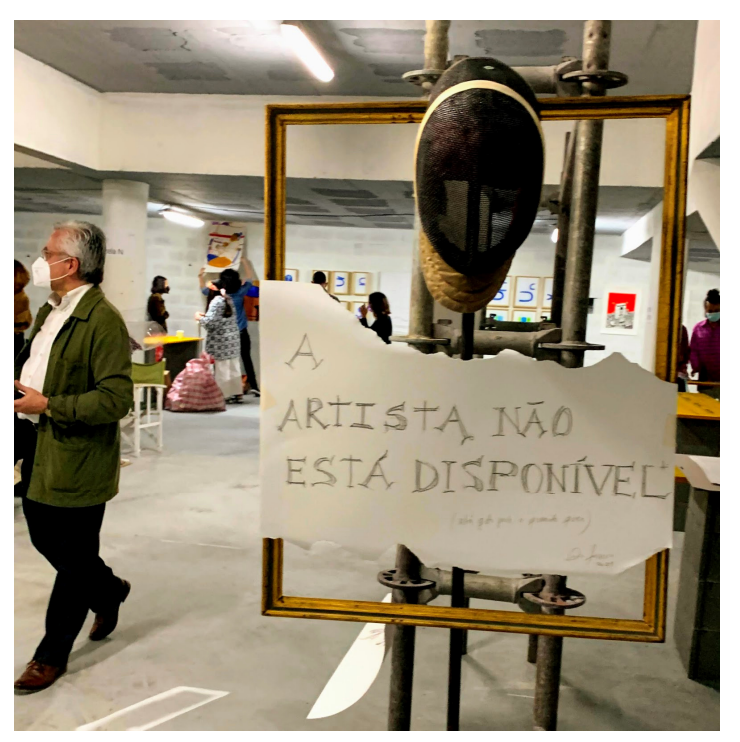

Figure 6. Mercado P'la Arte. 2021@ Created by author, with permission of the artist Ana Fonseca.

What conclusions can we draft? In response to the ongoing crisis, galleries expanded digital activities, improved content and communication and kept participating in art fairs hybrid models (online and in-presence). They have not reduced artists' representation, employees or wages. However, they did have an economic impact on their total revenue 
of $19.4 \%$ (between 2019 and 2020) but only 7.9\% between 2019 and 2021, lower than international figures.

Regarding online sales, there is a growing tendency, particularly at lower categories until EUR 50k, but it can be improved in the coming years. The lower use of the online sales channel may be related to the buyers' profile as they are generally local and experienced buyers, which is well-known to the gallerist. Another hypothesis is the low impact of foreign buyers, a category that is under attention in the coming years as potentially a new driver, as 34 galleries stated, considering them a key priority to improve their performance. Therefore, the art market seems a very innovative and resilient sector that needs to diversify sales channels and clients (collectors and buyers) and continue to pressure the Government to keep systematic acquisitions to reduce taxes in the art business.

\subsection{Spain: What Is the Extent of the Impact of COVID-19 in the Art Markets Sector?}

2020 has been a difficult year in every way and has highlighted all the shortcomings, inequalities, imbalances and structural defects that had been suffered for decades and that have now made more evident and visible the precariousness in which the Spanish art market lives. Before entering into our analysis of the sector in the year in question, it is important to mention the lack of specific data in the main source of information on the situation of arts and culture in Spain, such as the Yearbook of Cultural Statistics that the Ministry of Culture and Sports publishes every year: in the yearbook referring to the year 2020, Chapter IV.B, Sectorial Magnitudes, includes all sectors of the cultural field, including Bullfighting Affairs, but not artistic creation or its management, distribution and commercialization (Ministerio de la Cultura y Deporte 2020, p. 261).

It is very strange to find that art galleries do not appear among the cultural companies by main economic activity, in Chapter 2 of the Yearbook of Cultural Statistics. The commercial activity of the galleries, which not only provides jobs, export and import of goods and the internationalization of Spanish culture but also fundamentally helps the survival of an entire group of artists, is not taken into account in the main source of information statistics from the Ministry of Culture. In fact, art galleries are mentioned only among the cultural habits of the Spanish public, where it should be noted that visiting galleries, with $16 \%$ of the population assiduous to them, is well above attendance at classical music concerts, opera, ballet, or circus (Ministerio de la Cultura y Deporte 2020, pp. 35, 211). This lack of specific data on the activity of art galleries, a lack that they share with the scarce data collected in the state yearbooks regarding the activity of artists, leads us to look for information directly from the galleries themselves, a fundamental primary source that has been the basis of our study.

At the health level, the pandemic and the generalized state of alarm resulted in total confinement in Spain from 15 March to 21 June 2020. All commercial premises were closed except those considered of first necessity, which did not include contemporary art galleries. Therefore, the activity of the Spanish market was reduced during those more than three months to everything that could be conducted by telematic or telephone means. The ARCOMadrid fair had taken place shortly before, from 26 February to 1 March, and many of the transactions scheduled were then put on hold, as we will see below.

One week after the state of alarm was decreed in Spain on 14 March 2020, some of the professional associations that are members of the Sectorial Table of Contemporary Art prepared, at the request of the Ministry of Culture, reported on the immediate impact that the confinement and its restrictions were causing companies and professionals in the sector. Among them, we may distinguish the reports prepared by the Institute of Contemporary Art (IAC), an association that brings together nearly 500 professionals from the entire sector, with $18.6 \%$ of gallery owners (the second largest professional group in the association after artists), and the Consortium of Contemporary Art Galleries, the largest association of galleries in Spain with 95 associated art galleries. The results of both reports, to which another one was added, carried out by the Consortium one year after the beginning of the pandemic, served to assess not only the impact of the restrictions caused 
by the pandemic on an economic and labor level but also to determine which resistance and survival strategies had allowed the Spanish galleries to remain active during the year and what expectations for the immediate future they could venture ${ }^{30}$. We have also taken into consideration the report that Dr. Clare McAndrew issued in the summer of 2020, The Impact of COVID-19 on the Gallery Sector. A 2020 mid-year survey (McAndrew 2020), whose results have helped us to contextualize and compare global data with those provided by the Spanish market.

The Spanish market is a weak structure, made up mainly of small or medium-sized galleries with few employees (Pérez-Ibáñez 2018, p. 61), which since the 2008 crisis, has suffered a significant decline, intrinsically related to the crisis suffered by the entire art system, of which still has not fully recovered ${ }^{31}$. The impact is still evident at a social, economic and labor level more than a decade later, and its repercussion on the cultural industries led to the appearance of innovative management models aimed at improving the sustainability of managers and artists' work (Schiuma and Lerro 2017). Said new management models tended to generate new strategies that would allow the artistic sector to adapt frameworks applicable at the business level, based on the characteristics of cultural organizations and artists, adapting to their demands, needs, resources and their objectives of development and sustainability (Miranda de Almeida and Tejerina 2020). Thus, during the last decade, we have seen the paradigm of artistic management evolve and adapt to a framework in which globalization, virtuality, interconnection and the need to grow became common guidelines for action both in the public framework and in the private. Saving the inevitable distance, the phrase that Jerry Saltz applied in April 2020 to the international art system could also be used in Spain:

Over the last decade or so, the art world in peril has seemed to lose the ability to adapt. Or, rather, it now seems able to adapt only in one way, no matter the circumstances: by growing larger and busier. Expansion and more customers were the answers to everything (Saltz 2020).

This last decade has shown how the evolution of the business model of many galleries has been growing towards greater openness to the global market by participating in international fairs, and not only in large high-cache fairs such as ArtBasel, Frieze, FIAC but also in the many other satellite fairs that take place in these cities in the heat of the big ones and that also provide visibility and contact with new international markets that are sought by participating in them, such as Volta, Scope, NADA, Liste, etc. Likewise, there have been quite a few that have opened new, more spacious and versatile spaces or with an almost museum-like approach over the last decade (Sabrina Amrani in Madrid, ADN in Barcelona), and they have added new premises in other cities (Juan Silió in Santander and Madrid, Aural in Alicante and Madrid, Parra and Romero in Madrid and Ibiza, Xavier Fiol in Palma de Mallorca and Madrid, Rafael Ortiz in Seville and Madrid, Cayón in Madrid and Mahón, Nogueras Blanchard in Barcelona and Madrid) or even in other countries (Travesía Cuatro in Madrid and Mexico City, Maisterrabalbuena in Madrid and Lisbon, We Collect in Madrid and London). This expansion model, which proved to be the appropriate one when it was hoped to progressively emerge from the 2008 crisis and which was supported by global presence, has turned out to be an important handicap for companies, professionals and artists around the world in 2020, and especially in Spain, as indicated by the reports issued during the pandemic (Consorcio de Galerías de Arte Contemporáneo 2020; Consorcio de Galerías de Arte Contemporáneo 2021; IAC 2020).

When the confinement forced galleries to close, to cancel art fairs, planned exhibitions, commissions of artworks, the situation of the galleries and the rest of the professionals linked to their activity became red hot. The Consortium of Contemporary Art Galleries demanded before the Ministries of Culture and Finance the exclusion of this sector from access to the extraordinary measures to support business solvency in response to the COVID-19 pandemic contained in Royal Decree-Law 5/2021, of 12 March. However, both the aid for the "Promotion of contemporary Spanish art" and the aid for the "Modernization and digital innovation of the visual arts sector" received 149 and 154 applications 
submissions, mostly from art galleries, requesting support for the entire 2020 exhibition program, with some from artists and other professionals for specific projects. An average of $80 \%$ of the proposals submitted was granted, as evidenced by the listings issued by the Ministry. Public aid, also in the art gallery sector, has been essential to cope with the year of the pandemic.

As mentioned above, the art market in Spain is a weak structure in labor terms. In the report carried out by the IAC in March 2020, the fiscal situation of the respondents is divided into three large groups, data also representative of the entire sector: $56.8 \%$ of self-employed workers, $11.8 \%$ of entrepreneurs and $12.2 \%$ of employees, the rest being civil servants, retirees and workers on sick leave, with $4.7 \%$ unemployed. $8.2 \%$ of those surveyed state that they have been fired or have suffered permanent or temporary labor force adjustment plans since the beginning of this crisis. The report by the Consortium indicated that $70.9 \%$ of the participants did not reduce the number of employees, while $47.7 \%$ had taken advantage of temporal labor force adjustment plans, $60.9 \%$ of which expected to request a suspension of employment and $53.6 \%$ a reduction of working hours.

As stated by McAndrew (2020, p. 24) in her report, galleries in general face very tight employment structures, and during 2020 most of them had to furlough or permanently lay off staff in response to the crisis. One-third of galleries surveyed downsized their staff in the first half of 2020, and this was slightly higher for those with turnover above $\$ 10$ million, 37\% of which reported downsizing. Downsizing was also more common in certain geographic regions, most notably for galleries based in Africa (42\%), Germany and Spain (38\%) and the UK (36\%). However, engaging staff in remote work during lockdown was a common practice for all the galleries, and in many cases, it kept them from losing employees.

The use of new technologies and digital strategies has been decisive in consolidating the economic and commercial activity of Spanish galleries, as well as those of the rest of the world. As the McAndrew (2020, p. 36) report indicates, the growth of online sales accelerated in 2020 because of the absence of onsite sales. Online strategies and tools also moved to the forefront and became critical for most of the galleries' survival. The report by the Consortium analyzed the implementation and application of new digital strategies by Spanish galleries as a way to reach their audience and gain new markets. The study reveals that although it is true that more than $40 \%$ of the galleries have not implemented new methods in their day-to-day life, $46.5 \%$ of the participating galleries have mainly used social networks, and up to $12.8 \%$ have introduced streaming talks, reaching almost $20 \%$ as a new approach formula. The enhanced use of the gallery website has also been visible in up to $32.6 \%$ of the surveyed galleries. They have also used, although to a lesser extent (under 5\%), virtual exhibitions, such as the so-called Online Viewing Room (OVR), or the editing and broadcast of videos of temporary exhibitions as a formula to distribute contents among clients.

When asked about whether this online impulse has brought real sales or new clients, $50 \%$ of the galleries answered no, while a very close percentage, $48.8 \%$, affirmed that they had obtained responses to sales or increased clients through these channels.

As for sales, a high percentage of affirmative answers to the search for new strategies stands out, with up to $69.8 \%$ of galleries that have been forced to implement strategic alternatives or new formulas in the virtual space with online proposals, e-commerce through the website or different digital tools. Nevertheless, emphasis is placed on the importance and search for direct contact by the buyer with the artwork and with the in-person advice of the gallery owner. The new strategies respond as an alternative to the situation and connect well with new audiences and with a distant and younger type of collecting.

Regarding international art fairs, up to $26.7 \%$ of the galleries have canceled at least one and $18 \%$ up to three. Considering the expenses of these cancelations, $45.3 \%$ of the answering galleries had not advanced any payment. For their part, for those that had 
down-paid for the presence in canceled art fairs, an average of EUR 7611 loss was calculated in $42 \%$ of the galleries.

Thinking about new venues ahead, $18.6 \%$ of the galleries do not intend to take risks in 2021 , whereas $26.7 \%$ plan to attend up to three fairs in 2021 . However, uncertainty leads $14 \%$ of the galleries to believe that at least one of the art fairs in which they plan to participate will be postponed or cancelled, and $11.6 \%$ believe that up to two fairs.

The report by the Consortium states that up to $67.4 \%$ of the galleries have suffered sales cancellations. Most of those cancellations referred to artworks that were reserved between the ARCO art fair, which took place in early March 2020, and the first wave of the pandemic. It is also relevant to point out that galleries mention the proliferation of longer payment delays.

Concerning exhibitions, the Consortium concludes in this report that $24.4 \%$ of the galleries have not canceled exhibitions during 2020 since all exhibitions were either elongated or postponed during lockdown. However, $22.1 \%$ of the galleries did have to cancel exhibitions from their programming, falling between one to five exhibitions with an estimated loss of EUR 11,811 on average.

As for rescheduling derived from postponed exhibitions, $25.6 \%$ have had to postpone at least one exhibition, $15.1 \%$ three exhibitions, and $8.1 \%$ of the galleries up to seven exhibitions, assuming an average expenditure of EUR 21,794 for $20 \%$ of the galleries.

The Consortium was also interested in the subsidies and aids offered to gallery professionals by the Ministry of Culture and Sports. In the first place, the "Promotion of contemporary art" granted by the Directorate of Fine Arts of said Ministry, intended to cover the expenses of the exhibitions held in the gallery between March 2020 and March 2021. In total, $55.8 \%$ of the galleries requested one of those subsidies, of which $66.7 \%$ were granted. It is important to point out that gallerists refer to the long periods they must wait until the resources are provided, even after the subsidy has been granted.

In total, $39.5 \%$ of the gallerists positively value the format, conditions and requirements of these subsidies, considering that they convey to the collective they are aimed at. However, some galleries show negative assessments and considerations about the lack of real knowledge from the administration about how the art market really works, such as the following:

- capacity measures for commercial spaces that live off their sales have an impact on billing;

- $\quad$ there is a lack of consideration of galleries as a public service of cultural offer;

- the number of galleries and the subsidy amount must be increased, up to about EUR 20,000 , since the actual subsidies are insufficient in relation to the work and reality of art galleries;

- $\quad$ the most important thing that will help save the sector would be the elimination of VAT for one year and subsequently its reduction to $10 \%$;

- the needs of small galleries must be taken into account since their scope is the internal market.

Finally, the Consortium asked about the calculation of the economic deficit that the galleries had estimated at the end of 2020. It is presumed that $80.2 \%$ of the galleries have registered losses compared to 2019. Meanwhile, $13.9 \%$ did not declare any economic losses, and only $1.2 \%$ of the galleries have made a profit.

In general terms, based on the Spanish reports analyzed, the economic impact that COVID-19 has had on the activity of this sector is located in two large groups. For $67.7 \%$, the losses in economic terms are between EUR 20,000.00 and EUR 50,000.00, but there is a $21.6 \%$ group of art galleries and artistic managers for those who exceed EUR 50,000.00. The general impression of the dealers surveyed about the current situation is mostly critical, reaching $94.6 \%$ who consider that this crisis can have serious consequences beyond the medium term in their professional activity and in our sector. 
Strategies to Overcome the Crisis and Changing Priorities for the Sector

Spanish galleries, as well as all professional associations in the sector, have also made an effort by offering measures that can be implemented to help the market survive during and after the pandemic, facing a critical situation that's dimension and duration are unknown. They are fully aware of the gravity of the moment and the difficulties that are presented to all of the sectors, facing very serious problems. The following measures proposed are those that the galleries consider vital in order to plan the survival of a large part of the sector.

(a) The first group of specific measures for art galleries:

- Approving a subsidy for the production of exhibitions and canceled projects.

- Immediate help of $€ 2000$ per gallery.

- Streamlining of grants and contracts or institutional purchases.

- Lines of credit without interest and in the medium or long term. They can help to face not as many of the expenses derived from a specific or special project but the normal operating expenses.

- Financial help to produce exhibitions to be held in art galleries in Spain.

- Increasing the amount dedicated to aiding the promotion of art (participation in fairs), as well as reaching more galleries. Expediting the process of call and concession.

- Taking part in art fairs will be fundamental in order to regain activity. Applying and participating in them normally requires a significant advance payment, in what will undoubtedly be the worst moment of liquidity for galleries. On the other hand, due to the international nature of this crisis, many galleries have already faced the payment of international fairs that have either suffered a lot like those held in Spain or been delayed. Galleries have already paid all the costs of renting spaces in those art fairs, which will be held in what will still be a very complicated time, so it is foreseeable that they will throw more losses. Public aid to favor participation in fairs is therefore essential for the Spanish market. It is very important to point out that the previous measures would benefit the artists themselves and in a very direct way.

(b) The second group of measures in line with other companies and professionals in the sector:

- Postponement of tax payments.

- Continuing with the review and rethinking the cultural expense of $1.5 \%$ of all public infrastructure works by the Government, in permanent dialogue with the sector.

- Possibility of suspension for at least one- or two-month fees of the self-employed professionals and self-employed entrepreneurs.

(c) Other measures:

- Encouraging purchases of Spanish museums, public collections and institutions in Spanish galleries.

- Finally, opening a fluid and committed dialogue on the part of the ministry with the gallery sector to deal in depth with some of the eternally pending issues, especially the aforementioned VAT that the Spanish galleries suffer in comparison with the other cultural sectors.

The main conclusion that we can obtain from the data collected in the analyzed reports and the proposals offered is that the Spanish market, despite the efforts made to maintain a sustainable activity, needs the financial support of the administration to face the crisis that occurred during the COVID-19 pandemic, which, as we have mentioned, overcomes the previous crisis of 2008, which had not yet been overcome by the sector. The structural weakness of the Spanish market, its limited specific weight in the global market and its difficulty in being considered at the same level as other neighboring countries and the 
Global South context place it in a disadvantageous position that is difficult to overcome, a situation that the current pandemic crisis has only worsened.

\subsection{Brazil: What Is the Extent of the Impact of COVID-19 in the Art Markets Sector?}

Brazil is among the countries that suffered the most losses within the COVID-19 pandemic, a tragedy resulting from a set of wrong and non-scientific based decisions and measures taken by the Federal Government ${ }^{32}$. It should be said that Brazil did not have a true lockdown, at any moment, despite the gravity of the pandemic situation. In the void of federal policies, States and Cities adopt different strategies to deal with the situation.

São Paulo, the center of the art market, had, compared to the rest of the country, one of the most restrictive policies. There were two periods when galleries were not allowed to open: 20 March 2020 to 7 October 2020. New restrictions were imposed on 15 March 2021, when a second wave of the pandemic hit hard and only lasted until 18 April 2021. SP-Arte, the most important art fair in Latin America, usually scheduled in April, was cancelled in 2020, a few weeks before the opening, and postponed to 2021. It was planned to happen in August and now is expected to happen in October 2021. In Rio, measures were less restrictive, and a small in-presence edition of ArtRio happened in September 2020, with positive results according to some participating galleries. Nevertheless, many agents criticized the initiative, stating that it was still too early to host such an event.

Within a context of a pandemic out of control and weak public policies to fight its effects, it is left to the private sector (and to individuals) the choice about social distance and other measures to prevent contamination and dissemination of the virus. Since the first flexibilization of rules for opening to the public, most galleries started to operate by appointment and then open to the public with a limited number of visitors allowed. Some of them keep receiving visitors by appointment only. As we will see in the following pages, despite being immersed in the context of true chaos, not only in public health terms but also in political, social and economic terms, the art market and art market agents faced difficulties but reacted fast and remained active and resilient so far. As an art market agent put it: "The truth is, the pandemic did not affect millionaires ... rich people are still rich, the art market is surviving very well, it has shown an enormous resilience" ${ }^{\prime 33}$.

In this section, we will analyze the behavior of the Brazilian contemporary art market since the pandemic crisis started, exploring some aspects of its resilience and inquiring about the existence of significant structural changes in the way art galleries function. Our analysis will take data brought up by a survey conducted in September 2020 as a starting point, followed by a second survey applied between January and March 2021, complemented by wider field research in the process since March 2020. During this period, we contacted 80 art market players in total. We received 52 valid answers to the surveys. Semi-structured interviews, informal conversations and gallery visits allowed us to gather qualitative information from 23 art market players who shared their points of view about the impact of COVID-19 in the art market in Brazil and internationally. The ensemble of quantitative and qualitative data gathered so far allowed us to further understand the situation of the art market in a new context set up by the pandemic and to investigate conservation/adaptations/transformations of operating models deployed by Brazilian galleries.

The first studies on the impact of the pandemic on the art markets conducted in the USA and France (Art Dealers Association of America 2020; Comité Professionnel des Galeries d'Art 2020) published in the first half of 2020, pointed to a significant retraction in sales and the serious risk of definitive closure of around $30 \%$ of active galleries. Such a prognosis has passed a long way from what we can observe in Brazil.

There are no exact figures about Brazilian galleries' turnover in 2019 and 2020 available that could allow us to compare performance ${ }^{34}$ before and after the beginning of the sanitary crises, but a few other indicators clearly point out the resilience of the sector so far: there were no permanent closings of galleries due to the crisis; sales volume declined sharply in the first months and at the height of social isolation measures, but recovered shortly 
thereafter; a large part of formal jobs were kept, as well as the number of artists represented. Many of the current expenses for travel, art fairs and exhibitions have been reduced, allowing galleries to achieve a financial balance and even, in some cases, a greater profit than in previous years.

"In the very first months of the pandemic people did not know what to do, how to react, it was a shock. We expected it would not last ... then, we realized that we had to react, to find new ways to work, to help our artists . . " 35 .

The art market is doing well, in fact, we cannot complain, we see so many other cultural sectors struggling ... we are fine, our artists are surviving, suffering due the political context, but surviving." 36

The art market stands out, therefore, as a very privileged sector in the field of culture, ${ }^{37}$ which quickly adjusted to the new context, finding solutions to keep itself in business.

In September 2020, we conducted a Survey aiming to assess the impact of the COVID19 on the gallery's sector in Brazil, Argentina, Chile and Colombia upon the request of the Association of Brazilian Contemporary Art Galleries (ABACT). The main aspects analyzed concern the economic and structural impact of the pandemic on turnover and exports, workforce, management and operation models (digital strategies, participation in fairs, partnerships and relationship with artists). The results were published in December 2020, showing a significant resilience of the sector in the region (Esmanhotto and Fialho 2020).

In order to detect the economic impact of the pandemic on the art market, we analyzed the variation of sales results in the first three quarters of 2020 (Figure 7), compared to the equivalent period in 2019.

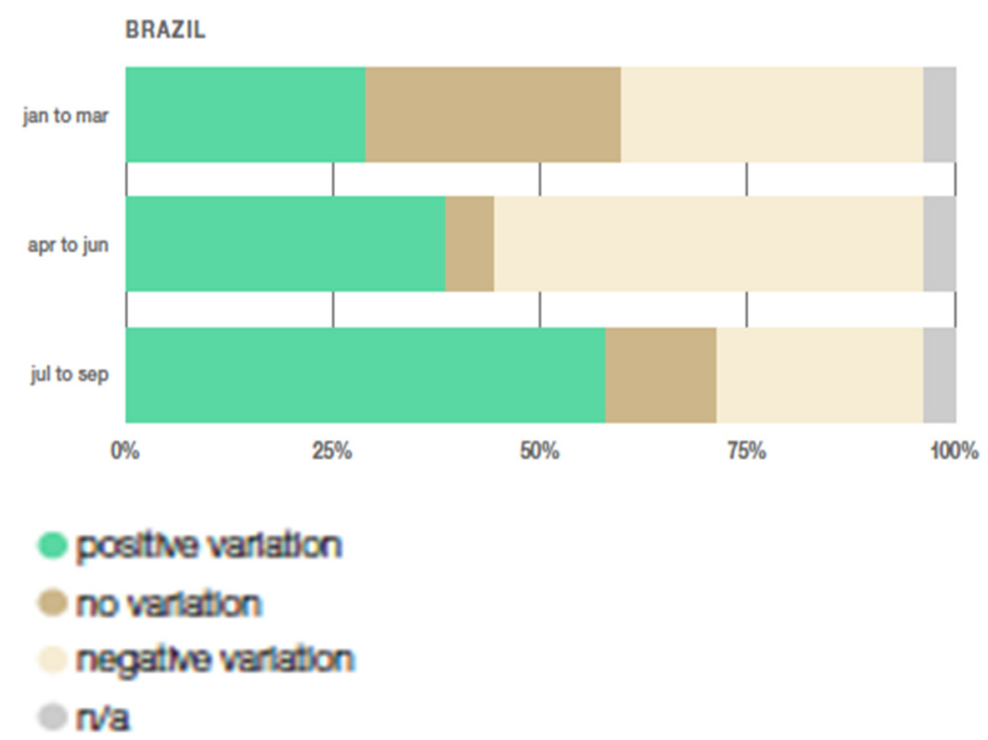

Figure 7. The variation in sales volume per quarter in 2020 (regarding the sales volume registered in 2019). Data source: Esmanhotto and Fialho (2020, p. 13), used with permission.

From January to March 2020, before the pandemic arrived in Brazil, a substantial contingent of Brazilian respondents (58\%) indicated having had sales equal to or higher than the previous year, against a smaller percentage $(38 \%)$ that indicated having had a volume of sales lower than the same period in 2019. It seems that the contemporary art market was performing better at the beginning of 2020 than in the previous year. The second quarter, from April to June, was the most difficult period for market players in Brazil, and $56 \%$ of the respondents registered a negative variation in their sales compared to 2019, which was expected considering that most activities of the art market were suspended or cancelled (art fairs and galleries exhibitions). Nevertheless, 40\% of respondents registered a positive variation in relation to 2019. In the third quarter, from July to September, there 
were already signs of recovery: $55 \%$ of respondents indicated a positive variation in the business carried out in the period, $14 \%$ did not register variation, and $27 \%$ registered a negative variation compared to the same period in 2019.

One can consider that perhaps galleries want to pass on a positive image, an image of stability and resilience in order to hold the trust of their collectors, and that motivation may bias their answers about sales results. However, other indicators support the perception about the resilience of the sector: no galleries closed, they kept employees and artists, and some galleries even opened new premises in Brazil and abroad.

There were some testimonies of struggle as well; a gallerist who had to shut down his second space said that he was reducing all possible fixed costs, but that was not being easy to balance out sales and expenses ${ }^{38}$.

Some gallerists declared themselves surprised by the profits they were able to make and wondered if their results were extraordinary if compared to others. In fact, the qualitative research proved that this was the case of several galleries, a fact that was also noticed by the press (Ferraz 2020). Analysis of the variation in fixed costs of the players that operate in the market can help to understand the resilience of the sector and the good business results obtained by a significant part of the respondents, many with better results than those registered in 2019. The functioning of the art market before the pandemic was supported by a model based on international fairs and trips, especially for the most professionalized and internationalized players. Such a model implied quite high operating costs. Renegotiation of rent, cancellation of trips, fairs and exhibitions, expenses with wages and production of works were the most mentioned answers for the reduction of recurrent costs during the period of social isolation.

The majority of galleries surveyed managed to keep their workforce since the beginning of the pandemic. There were some dismissals and also hires, but the overall trend was to sustain the existing jobs, as shown in Table 2, bellow.

Table 2. Galleries' employees after COVID-19.

\begin{tabular}{cc}
\hline After COVID-19 Galleries & \\
\hline Kept the same team & $63 \%$ \\
There were dismissals & $18 \%$ \\
There were dismissals and hires & $12 \%$ \\
There were hires & $7 \%$ \\
\hline
\end{tabular}

Data source: The author, based on (Esmanhotto and Fialho 2020).

The preservation of work placements in the art market contrasts with information about employment, and more specifically about employment in the cultural sector, which lost about 900 thousand work placements in 2020 (Observatório do Itaú Cultural 2020).

Among the companies that registered dismissals, the great majority only fired 12 employees. This data contradicts one of the very few findings about Brazilian galleries mentioned in an international report: according to The Impact of COVID-19 on the Gallery sector. A 2020 mid-year survey (McAndrew 2020, p. 24), galleries would have reduced their size in terms of the number of employees, losing an average of four employees, highlighting that the biggest losses occurred between multi-premise galleries and that Brazil would have the highest national average percentage of loss: eight employees per gallery, a percentage that is certainly distorted by the small representativeness of Brazilian galleries in the surveyed sample.

Art market players used to complain a lot about the insufficient support they get from the Government, even before the pandemic crisis. However, it is important to note that the contemporary art market in Brazil did benefit from some public policies, even though it is hard to measure their exact contribution to the capacity of galleries to face the crisis. According to our research, a significant part of art market players (71\%) counted on resources and public policies to face the crisis caused by the pandemic in the first months of 2020. The initiatives mentioned most often were the support offered by the 
Association of Brazilian Contemporary Art Galleries (ABACT) together with Apex-Brasil, through the program Latitude ${ }^{39}$, which is a program that aims for the internationalization of the market to secure a more relevant digital presence of galleries, mentioned by $30 \%$ of participants. Additionally, federal emergency credit to support employment maintenance and postponement of tax payment deadlines, mentioned by $18 \%$ of them.

Strategies to Overcome the Crisis and Changing Priorities for the Sector

In Brazil, the growing process of internationalization of the primary art market started in the mid-2000s and is attested by a significant presence of Brazilian galleries in the international circuit of art fairs, the diversification of the destinations of international sales, the growth of sales made to private and institutional collectors, the opening of branches of Brazilian galleries abroad and the participation of Brazilian artists in programs of relevant international institutions, which are all factors that are reflected in the growth of the volume of exports made by the visual arts sector ${ }^{40}$ in a broader way, as shown in previous publications (Fialho 2019).

The growth of international activities has been consistent, although national sales still drive most of the galleries' revenue (on average more than $80 \%$ in past years (Fialho 2019; ABACT / Latitude 2012, 2013, 2014, 2015, 2016, 2018). The 20\% share of international sales may not seem significant; nevertheless, the international dimension of the business is not related to sales revenue only, but it is actively linked with the legitimation of artists and also with the galleries' reputation (Moulin [2003] 2007, pp. 25-26) and therefore is considered key by most galleries.

During the pandemic, it was expected that international activities and sales would drop. Indeed, the fall of exports among galleries is estimated at over $85 \%$ in 2020 , compared to 2019 (Apex-Brasil 2021). However, considering the relatively low share of international sales over the years, one can presume that this fall has little impact on the revenue of most galleries, which would help to understand the positive results obtained by a considerable part of them in 2020. What is interesting to note, nevertheless, is that despite the decrease in international sales, market players in Brazil remained active in the international market in 2020 and that internationalization is not only a goal but continues to be an important strategy for galleries' development.

Until the advent of the pandemic, one of the most important platforms for connecting Brazilian galleries with the international circuit and the main sales channel abroad were international art fairs. A pressing issue, since art fairs were canceled, postponed and transformed into online events, was to understand the ability of Brazilian galleries to sell and to remain active on the international circuit.

The first survey carried out, covering the period from January to September 2020, indicated that about $66 \%$ of respondents made sales abroad, and within this universe, the majority made sales in equal or less volume than in the previous year (Figure 8). The survey also made it possible to identify that the younger and smaller galleries had greater difficulty in accessing the international market and that the larger, more experienced and internationalized galleries made international sales in greater volume and frequency.

An update of the research was conducted at the beginning of 2021, indicating that throughout the year 2020, $72 \%$ of the galleries made international sales. Among the respondents, there is a wide variation in the weight that international sales represented in the business of galleries in 2020, and some, very internationalized, especially those holding branches abroad, reported that sales made to other territories ranged from $50 \%$ to $85 \%$. Conversely, galleries in the initial stage of internationalization had only $1 \%$ or $2 \%$ of their total sales volume related to international sales. 


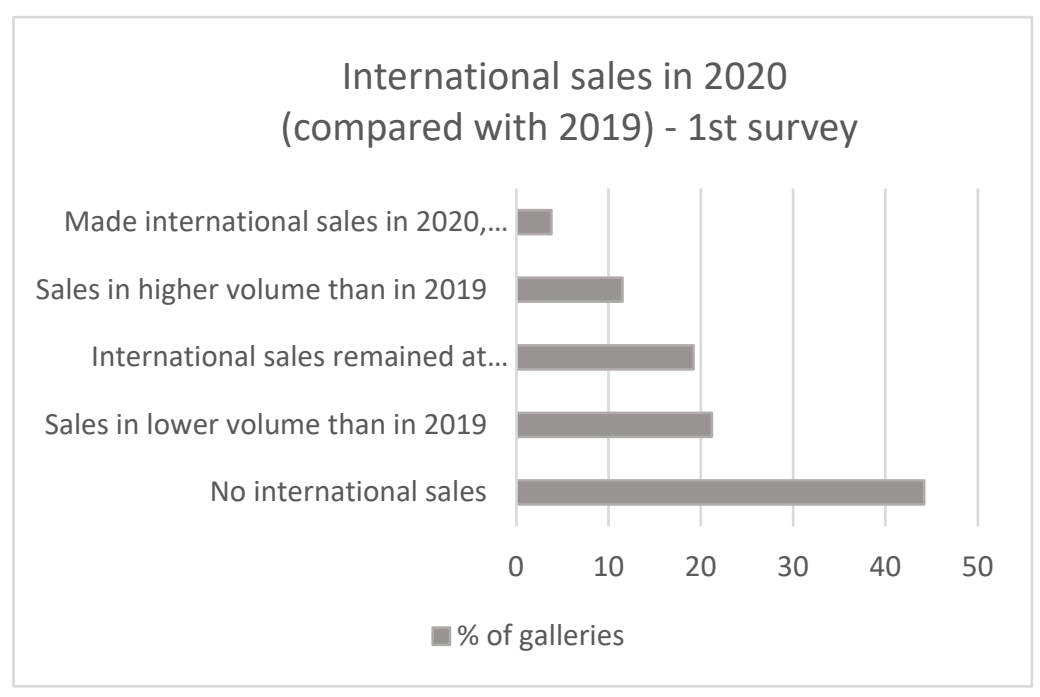

Figure 8. International sales-1st survey (January-September 2020). Data source: Author's designed graphic, after Esmanhotto and Fialho (2020).

The following chart in Figure 9 shows the weight of international sales in relation to the total sales made in 2020.

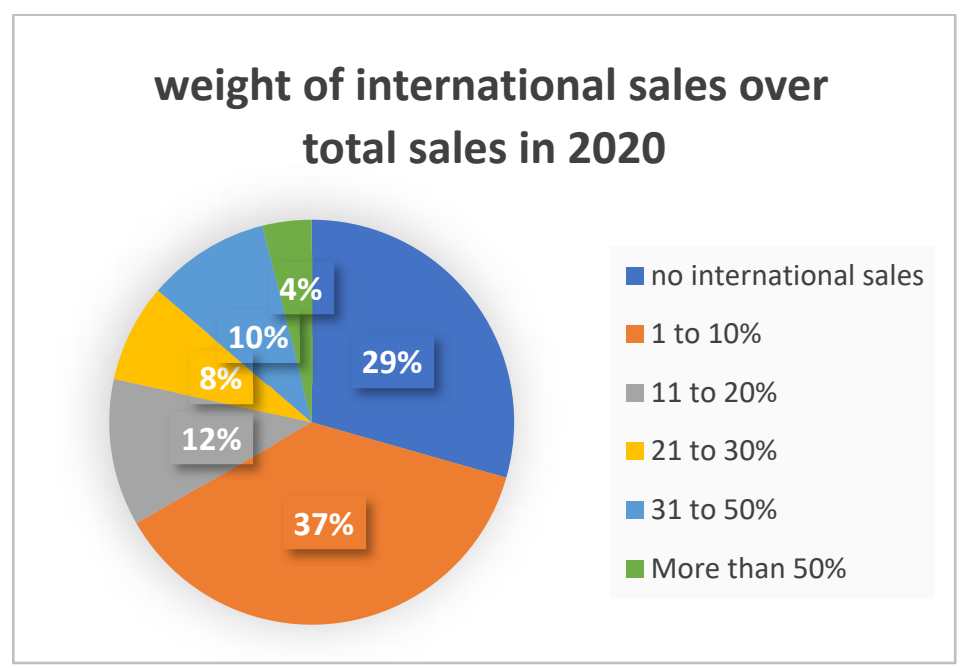

Figure 9. International sales share over total sales in 2020 (\% of galleries). Data source: Graphic designed by the author.

The percentage of international sales was not so significant before the pandemic, either, as we already pointed out. According to Latitude Contemporary Art Market Reports, from 2011 to 2014, the average percentage of sales made to the international market over the total sales of galleries did not change, ranging from $14 \%$ to $15 \%$. There was a significant increase in exports, but it was accompanied by a growth in domestic sales, and the proportion remained unchanged. The same source indicated a change in 2015, when this percentage increased to $20 \%$, returning to a percentage close to the historical series in 2017: $16.35 \%{ }^{41}$.

These data show that Brazilian galleries are strongly anchored in sales to the domestic market, and one can suppose that most of them do not depend on international sales to continue their business in economic terms, which could be a positive factor in the context of the pandemic, when strengthening the ties with reachable clients seem so important. Most galleries underlined the importance of proximity strategies to cross the period of crisis without losing sight of their international ambitions. However, although the volume of sales abroad is not relevant in percentage and these sales have decreased in the context 
of the pandemic, what we would like to highlight is that more than $70 \%$ of the surveyed galleries found ways to operate in the international market, even without the possibility of traveling and participating in art fairs, staying in their former business location, far away from the center of international market operations. Reaching the international market remains important and is part of the galleries' strategies for business development at large.

We were able to evaluate the destination countries of the sales made and compare them with the history of destinations registered by the galleries. Since data started being monitored (2012), every year, galleries would sell to over twenty countries. In 2017, 22 destinations were mentioned, the United States keeping the top position of international sales made by Brazilian galleries. Other recurring destinations used to be the United Kingdom, Spain, France, Switzerland and Colombia (ABACT/Latitude 2018).

In 2020, galleries reported sales to 25 countries, more than reported in 2017. The United States remained the main destination, mentioned by 25 galleries, almost half of all surveyed galleries, followed by the United Kingdom and Switzerland, as we can see in the graphic below in Figure 10.

\section{Destination of international sales}

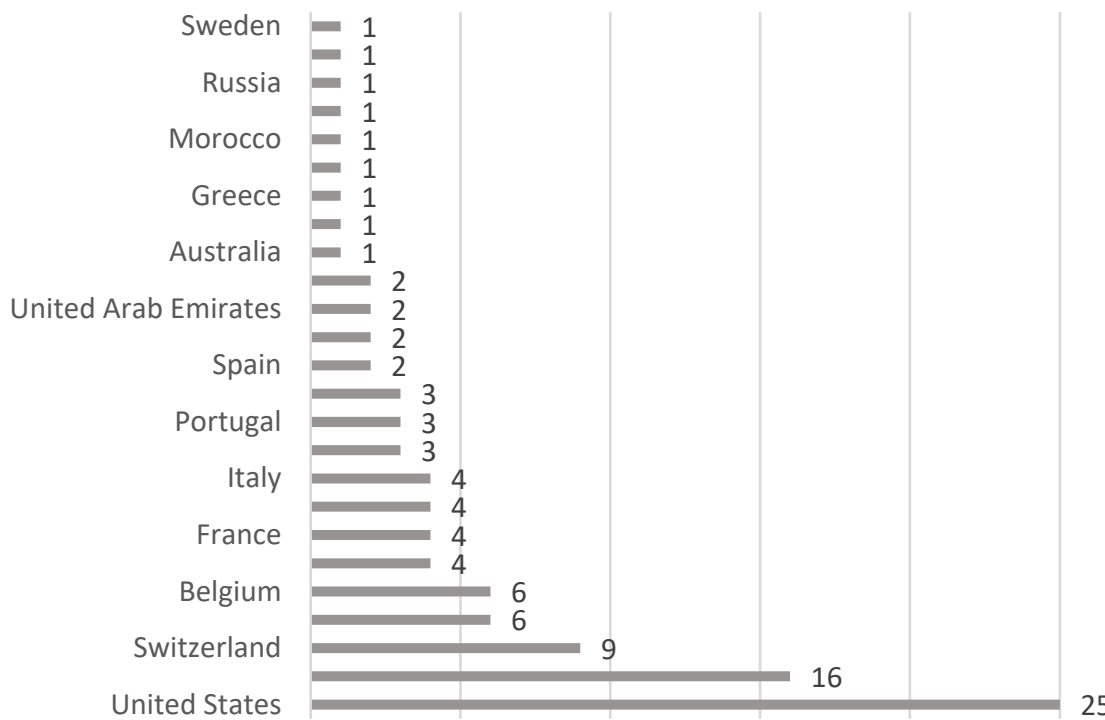

Amount of Sales...

Figure 10. The destination of international sales made by Brazilian galleries (by the absolute number of galleries). Data source: Graphic designed by the author.

The realization of sales to such diverse destinations to different countries and institutions $^{42}$ at a distance, through different new tools and platforms, which were not commonly used before the pandemic, is an important fact for thinking about internationalization processes in the post-pandemic context, where, it seems, many market agents do not intend to fully return to the previous business model, highly focused on frequent trips and participation in a large number of international fairs. Many of them declared to have the intention of balancing out the participation in in-presence international art fairs and online art fairs and to keep investing in their digital presence to reach international audiences. Another aspect that we would like to draw attention to is that the transposition of face-to-face activities into the digital environment allowed the galleries to remain connected with the international circuit and opened new business opportunities for some agents. However, we also note that the ability to reach internationally through digital initiatives is not equally distributed among the galleries and that this capacity is still closely related to the visibility and recognition achieved by the galleries before the advent of the pandemic. 
The qualitative analysis of international sales made by galleries indicates that the ability to reach international customers in the context of social distance and restrictions on circulation is largely related to previously established contact networks. The most important sales were made mainly to recurring customers $(29 \%)$ and contacts made at face-to-face fairs $(18 \%)$, followed by sales made through marketplaces $(17 \%)$, online fairs $(14 \%)$, social networks $(12 \%)$ and in-person at the gallery $(10 \%)$, which shows that the digital transition is not enough to ensure this international reach (as it is not enough to keep the sales in the national market either).

With these caveats in mind, it is worth noting that the presence in marketplaces and online fairs allowed some galleries to establish contact with customers and destinations never before reached. A young gallery, still in the initial process of internationalization, reported, for example, that a sale to South Korea was made through a marketplace.

Even though it is hard to measure, the capacity of galleries to face the crisis is also related to some public policies. A significant part of art market players $(71 \%)$ counted on resources and public policies to face the crisis caused by the pandemic in the first months of 2020. The initiatives mentioned most often were the support offered by the Association of Brazilian Contemporary Art Galleries (ABACT) together with Apex-Brasil, through the program Latitude ${ }^{43}$, which is a program that aims at the internationalization of the market, to secure a more relevant digital presence of galleries, mentioned by $30 \%$ of participants. Additionally, federal emergency credit to support employment maintenance and postponement of tax payment deadlines, mentioned by $18 \%$ of them.

Another aspect that called our attention refers to an artist's representation. The surveyed galleries represent a universe of about 1200 artists, or about 23 artists per gallery on average, a contingent that has not undergone significant variation due to the pandemic. There are great differences in scale of artists representation, small galleries representing only 6 artists, and, on the other end, a gallery with multiple sites, representing a total of 61 artists.

If the galleries retained the number of artists represented, as shown in Table 3, we can consider that the galleries, for the most part, did not reduce their size, scale and structure. It is also a sign of the resilience of the market.

Table 3. Artists' representation in Brazilian galleries.

\begin{tabular}{cc}
\hline Galleries in Brazil-Artists Representation & $67.4 \%$ \\
Galleries that kept the same number of artists represented & $23 \%$ \\
Galleries that increased artists represented & $9.6 \%$ \\
Galleries that decreased artists represented & $66 \%$ \\
Galleries that changed the way they work with artists & $34 \%$ \\
Galleries that did not change the way they work with artists &
\end{tabular}

It is interesting to note that, on the one hand, there is significant stability in relation to the number of artists represented and, on the other, a clear indication of ongoing changes in the way galleries work with artists, suggesting the rise of new roles and new functions.

The stability of the artist's roster among the majority of galleries and the emphasis they gave to the improvement of communication and greater proximity with artists may suggest an effort made, by gallery owners, to keep and support artists during the crisis.

Galleries registering changes in the way they related to artists pointed out that they engage them in activities they did not use to participate before, mainly in the production of new contends for digital platforms ${ }^{44}$ but also in building up strategies to respond to the crises, including some new sales activities.

The concern with strengthening ties and maintaining support for the represented artists was repeatedly affirmed by several galleries. However, this greater proximity to represented artists also derives from the understanding that artists could contribute to finding creative solutions to go through a period of crisis. 
In addition to the change in the way of working with the represented artists, some galleries also reported that they are exploring new partnerships, taking advantage of the digital environment to develop special projects with artists who are not part of the represented artists team, with whom they wish to establish some type of collaboration and, eventually, a future representation.

Periods of crisis tend to bring artists to an even more uncertain condition (Menger 2012), and the responses of galleries can go towards two opposite directions: some galleries tend to work with more stable values, focusing their energy on promoting well-established artists and not committing to emerging ones. Others take a riskier path by welcoming new artists to the market and experimenting with new forms to work with them.

The research allowed us to identify significant changes arising from the context of the pandemic. More than half of the respondents (66\%) registered some change in the way they relate to artists. Among the most frequent changes mentioned by market players are those related to the method of communication, the collaboration for the production of online content, the engagement of artists in the dissemination of content and sales actions. They also mentioned collaborative initiatives and partnerships involving artists represented, other galleries and art spaces, indicating greater proximity and closer exchanges. The galleries also mentioned the reformulation of the model of contracts, the reduction of aid for the production of works, changes of the monthly amounts paid, agreements allowing the direct sale of artists in their studios and some change of artists represented.

One aspect that was not detected in the majority of the group of galleries but still is worth notice is the flexibilization of contracts in terms of exclusivity of representation and also commercialization. Some galleries reported to have agreed artists could sell directly from their studios and participate in commercial initiatives led by other agents. This flexibility may represent a significant rupture in some conventions, in Howard Becker terms (Becker [1982] 2010, pp. 59, 113) largely adopted by art market players, such as those artists represented by galleries would not get directly involved in commercial activities and sales negotiations; artists represented by galleries would not sell directly to buyers; and more established galleries and artists would have a clear agreement about representation and territorial exclusivity, with strict contracts often set by the main gallery representing the artist, followed by secondary galleries.

We would like to suggest here that innovation and revision of conventions may be a process that starts with some players, the ones who dare to break conventions, and may spread among the market at large within time.

\section{Results and Discussion}

The art markets in Portugal, Spain and Brazil seem to overcome with innovation and resilience the external shock of the COVID-19 pandemic. In the previous period of crisis, art proved to be a useful tool for the recovery of the economy due to its symbolic value (Bourdieu 2011) and to its capacity of being a "resistance" commodity (Moulin [1967] 1989), potentially desirable for investors and collectors (Roque 2020a, 2020b).

In times of confinement and in the subsequent return to a "new normal" not yet generalized, the resilience of contemporary art galleries has manifested itself on two different fronts: on the one hand, in the immediate adaptation to the impossibility of face-to-face access, cancellation of exhibitions at their venues and participation in art fairs. Adapting to the digital environment is not so easy in all markets, especially in those where small and medium-sized galleries with reduced resources prevail, such as the Spanish, Portuguese and Brazilian markets. The absence of large platforms that facilitate digital access for galleries to the global environment of the international market hinders any strategy developed by galleries and makes it more valuable. On the other hand, the resilience of the galleries in the area we analyzed is shown in the immediate adjustment to an uncertain future in terms of the calendar of upcoming fairs, access to new markets and clients and new conditions in the commercial activity itself, with scarce support of public policies. 
Going back to the questions raised in the introduction of this article of how Portugal, Spain and Brazil are responding to the new context, in these three countries, although their specificities in terms of economic development and cultural policies in the sector, art agents (gallerists, artists) are reacting with decidedness and adopting measures that can minimize the economic impact of the crisis. The adaptability of contemporary art galleries in the three countries, from their peripheral position in the global market, is demonstrating a capacity to overcome the crisis caused by the health emergency that we can consider resilient, quickly adapting to unstable conditions in the near future and preparing for an uncertain medium term in difficult economic and professional conditions.

Data analysis and field-based observation showed a strong commitment by gallerists in overcoming the pandemic crisis: during the lockdown, gallerists worked backstage and improving contents and communication digitally, strongly participating in art fairs hybrid models (online and in-presence) and marketplaces. Digital strategies are not sufficient alone, so they are combined with the intensification of communication with collectors and investment in proximity networks. Some other findings are related to specific contexts: the majority of Portuguese and Spanish gallerists claim financial support from the State for participation in international art fairs, which are important platforms for the internationalization of artists and market players amidst international museum directors, collectors and curators, and, indirectly, it is also relevant for the country as it represents an image of strong contemporary culture and cosmopolitan status. In Brazil, the sector shows a strong commitment to internationalization, despite the challenges and changes required to keep galleries international reach, and this seems to be a valuable lesson for contemporary art galleries based in Portugal and Spain.

Despite the variation in galleries' revenues, it did not impact on artists representation, nor in the employment sector. In operational terms, it is noticed a reinforcement of the strategy of promoting ties with usual and experienced collectors, although looking for new buyers is also a relevant action to follow.

Concerning the main changes identified in the art market's activities, the digital turn seems irreversible. Online sales increased significantly in the pandemic period, and there is still a great potential for growth as we believe that the use of this tool will normalize and streamline the art business, particularly in the highest categories of segmentation value. When we observe the use of digital tools on an international level, aggregate online sales of art and antiques reached a record high of $\$ 12.4$ billion, doubling in value the previous year. These high figures mean agents were looking for alternatives to the general market fall $^{45}$. Digital platforms are becoming increasingly important in various markets domains, changing ways of production, circulation, mediation, and consumption of artistic proposals. Besides the overuse of this tool, many art agents seem not to be convinced that the virtual will substitute the face-to-face model (Anonymous 2020a), and some others advocate for a hybrid operating model on-offline.

According to many art market agents interviewed, digital art fairs did not bring great sales results so far, but they also cost much less, and most of them intend to continue to participate in future initiatives. Probably one of the long-term effects of COVID-19 will be a paradigm shift from the in-person art fairs to the hybrid models, both online and in-presence, as much as the downsized scale of these events, they may become more competitive and the reduction of the number of in-presence art fairs attendance per gallery.

Another important aspect of recent change detected by the research is the growth of collaborative initiatives and the revision of models for artists' representation, exhibitions, circulation and commercialization of artworks. Some of the changes here discussed were a response to the pandemic context, but nevertheless, they may not be circumstantial; in fact, they seem to be long-lasting effects that may transform the dynamics of the art market in the aftermath of COVID-19.

Regarding the most welcome strategies to overcome the external COVID-19 shock and considering the primary art market consensually as an economic driver, Portugal, Spain and Brazil have in common the challenge of stimulating political structures to implement 
measures capable of fostering the art markets sector in a systematic way. Enhancing the deficient policies in supporting fine arts and the contemporary art sector is critical for the three countries. A stronger convergence of private initiatives led by sectorial entities and public policy for the sector could represent a sign of confidence within society and create a positive dynamic between players. Among the policies, education towards arts and culture is a desirable structural action, as some of the reports still point to low levels of cultural practices, namely in Portugal. The articulation between the public and private institutions in the field of acquisitions involving private collectors and investors would be also desirable.

The findings presented in this paper refer to an ongoing phenomenon. The pandemic is not over, and its effects will continue to be felt within the cultural sector for a while. We hope our contribution to this publication will be a useful tool for further discussion and research. We believe that sharing knowledge and strengthening collaboration are valuable ways to contribute to the development of the art markets studies field. We hope this paper can also be useful for decision making, policy building and advocacy in favor of the recovery and further development of the sector in Portugal, Spain and Brazil.

Author Contributions: Conceptualization, A.D., and A.L.F., and M.P.-I.; methodology, A.D., and A.L.F., and M.P.-I.; software, A.D., and A.L.F., and M.P.-I.; validation, A.D., and A.L.F., and M.P.-I.; formal analysis, A.D., and A.L.F., and M.P.-I.; investigation, A.D., and A.L.F., and M.P.-I.; resources, A.D., and A.L.F., and M.P.-I.; data curation, A.D., and A.L.F., and M.P.-I.; writing-original draft preparation, A.D., and A.L.F., and M.P.-I.; writing-review and editing, A.D., and A.L.F., and M.P.-I.; visualization, A.D., and A.L.F., and M.P.-I.; supervision, A.D., and A.L.F., and M.P.-I. All authors have read and agreed to the published version of the manuscript.

Funding: This research received no external funding.

Institutional Review Board Statement: Not applicable.

Informed Consent Statement: Not applicable.

Conflicts of Interest: The authors declare no conflict of interest.

\section{Notes}

1 Some examples: TEFAF 2020 was interrupted; Art Basel Hong Kong 2020, ARCOlisboa 2020, SP-Arte 2020, Lisbon Art Antiques Fair, LAAF 2020, and among others, were cancelled; ARCOmadrid 2021 and SP-Arte 2021, among others, were postponed. The global estimate of cancellations in 2020 is 61\% (McAndrew 2021, p. 20), but empirical observation indicates that the percentage can be higher. Still, the results of the art markets reports, such as the reports issued by Arts Economics and Dr. Clare McAndrew, must be handled with reservation as the estimated figures on the primary art markets show huge variations due to the lack of information, particularly of private sales. Nevertheless, sometimes academics use this data (Velthuis and Curioni 2015; Zarobell 2017).

2 None of the three countries would fit the small group of "prescripteurs" of contemporary art (Quemin 2002) or the start system (Quemin 2013a).

3 For example, the contemporary art fairs, e.g., ARCOmadrid, Drawing Room, JustMad, launched a branch in Lisbon, since 2016 (Duarte 2020).

4 A recent initiative by 3 Brazilian galleries-Fortes D'Aloia and Gabriel, Galeria Luisa Strina and Sé-is presented in Portugal during the 2021 summer: "O Canto do Bode (The Song of the Goat) is a collaborative exhibition at the Casa da Cultura da Comporta. Three Brazilian galleries from different generations join global initiatives in building new working models in an unprecedented context for the art circuit. In total, 32 artists represented by the galleries, in addition to 4 guest artists, will occupy a former cinema within the historic Casa da Cultura at the Herdade da Comporta Foundation, which becomes a pop-up gallery in the European summer." Luisa Strina and Fortes, d'Aloia e Gabriel are very well-established Brazilian galleries with a strong international presence, being part of the most prestigious art fairs as Art Basel and Frieze for decades (Fortes, d'Aloia e Gabriel also keeps an office in Lisbon since 2014), and Sé is a younger but internationally ascending gallery. The choice of hosting an event in Portugal is mentioned by gallery owners as part of a plan to strengthen ties with the country and to respond to artists' expectations. Another example is Nowhere Lisbon, an independent space founded by Brazilian curator Cristiana Tejo and Brazilian artist Marilá Dardot in 2018. Shortly after the beginning of the pandemic, Tejo and Dardot, together with other artists and art market players, launched, from Lisbon, a hybrid commercial initiative called Quarantine, aiming to help artists and social projects to face the crisis. 
5 The team had already organized workshops and lectures between its members, and a conference on the Art Market and the Global South, in Lisbon. For further information about the cluster's aim, see (Anonymous 2019): “Cluster art market and collection." Available online: https:/ /ihapgmercado.weebly.com/cluster-amc.html (accessed on 28 May 2021).

6 We have not segmented the art markets typologies in terms of artistic representation because some of the categories would be under-represented in the three countries, for example, internationally recognized talents (Moureau and Sagot-Duvauroux 2006, pp. 23-27) or the blue-chip category.

7 The international dimension that participation in art fairs allows is of relevance and contributes to the ranking of the gallery performance and its artists (Quemin 2020, 2013b). Most Brazilian and some Spanish galleries in this study do have that international dimension, while the majority of Portuguese galleries have a local scope.

8 Mapa das Artes is a yearly update website, created in 2016, with information about galleries, museums and art centers active in the city (Anonymous 2021b).

9 The phone contact led us to exclude sixteen galleries from the first list because we concluded they had no activity in the years under study. The final number was seventy.

10 We do not pretend to have gathered all active art galleries in Portugal (there is certainly more than seventy), but we did have the cooperation of the most relevant between this set, and we estimate to have a very representative sample.

11 This declaration follows up the Decree of the President of the Portuguese Republic, published on 18 March (Decreto do Presidente da República $\mathrm{n}^{\circ} 14-\mathrm{A} / 2020$ de 18 de março).

12 The others cities pointed were: Coimbra, Figueira da Foz, Braga, Ponta Delgada in Ílha dos Açores, Ílhavo, Funchal in Ílha da Madeira. In Figure 1, the lowest percentage in orange is $10.9 \%$ and in red is $6.5 \%$. In Portugal, the share of employment in creative and cultural sectors showed figures between $0.5 \%$ to $1 \%$. Source OECD 2020 Regional statistics. To further understand the simplified Lay-off, see the information on the Government website (Anonymous 2021c). It must be underlined that all the conclusions of this topic are conditioned by the category's segmentation (intervals of revenue defined in the survey to respect the privacy of the data).

The global sales of art and antiques down 22\% from 2019 (McAndrew 2021, p. 17). In France, the primary art market sector also showed a down: a survey conducted by the Comité Professionnel des Galeries d'Art concluded for a total loss of 184 Million Euros between February and June 2020, and one-third of French art galleries were at risk of shutting down (Comité Professionnel des Galeries d'Art 2020).

These calculations were made using corrections for an estimation of 39 answers for each year.

Internationally, the mega-galleries tend to dominate online sales and to face the crisis easier. The pandemic will probably underline the gap between art market players (Xydas 2020, p. 37).

This information was given to the author by Bruno Múrias through telephone message in 28 April 2021. Plus, he confirms in-presence on 15 May, stating that it was worth it because he sold well.

The Portuguese Association of Art Galleries (APGA) existed already but lost activity; it is known that it was created a new association in 2019, named Exhibitio, but its activity is not known yet.

The Drawing Room Lisbon is focused on drawing and worked successfully for gallerists (Anonymous 2020b).

As previously said, the art fairs for primary markets in Lisbon are branches from Madrid, which reinforces the common market at the Iberian Peninsula. ARCOlisboa, the international art fair for contemporary art, was launched in 2016, as an initiative from IFEMA, a consortium formed by the Madrid Regional Government, the Madrid City Council, the Chamber of Commerce and Industry and Fundación Obra Social y Monte Piedad de Madrid, with the support of the Ministry of Culture, from Portugal, the Lisbon City Council, and the Portuguese Tourism. The JustLx, devoted to emergent art, is promoted by the Spanish company ArtFairs, and it had its first edition in 2018, in Lisbon, as an ARCOlisboa satellite art fair.

24 The new acquisitions, and the former collection, will be available among those institutions (apparently, in a political of decentralization scope). See Resolução de Conselho de Ministros n 50/2021 (2021) (Diário da República n 91/2021, Série I, 11 May 2021). Abstract: Cria a Rede Portuguesa de Arte Contemporânea e o Curador da Coleção de Arte Contemporânea do Estado (Creates the Portuguese Contemporary Art Network and the Curator of the State Contemporary Art Collection).

Acquisitions have been made annually by a commission, the first between 2016-2019, the second commission acted between 2019-2021 (Matos and Faro 2021). Besides artworks acquisitions, the Municipality launched a specific program for independent workers of the cultural sector, called the Social Emergency Fund. In this context, curators have applied, opening exhibitions in galleries (for example, in the Balcony Gallery).

26 According to Observatório Português das Atividades Culturais, circa half of artists and professionals of art and culture have a wage of EUR 600 per month, an amount close to the minimum wage (Neves et al. 2021a, p. 8). 
Sarmento, from 1977, also named "Survey to 60 artists," Sara and André surveyed 471 artists by email, addressing four questions about the COVID-19 representation, its impact on artists' life and work, and how they see the future after the pandemic crisis. There is a published version with the number of participants (263) (Sara and André 2020b) and an online version: Sara and André (2020a). Inquérito a 471 artistas. Contemporânea. Available online: https:/ / contemporanea.pt/edicoes/inquerito-471-artistas/ inquerito-471-artistas (accessed on 17 May 2021).

The pandemic crisis showed the need for social protection to artists (and professionals of culture) and the implications it has in this legal frame. According to OPAC, $88 \%$ of the inquiries showed a discontinuity contributory career (Neves et al. 2021b). It is under public discussion until 17 June 2021: see the Decree-Law that approves the Statute of Professionals in the Area of Culture. Anonymous (2021d). "Decreto-Lei que aprova o Estatuto dos profissionais na área da cultura". Available online: https: / / www.consultalex.gov.pt/ConsultaPublica_Detail.aspx?Consulta_Id=195 (accessed on 17 May 2021).

The idea is to have a monthly art fair, and artists apply to the platform to participate. Mercado P'la Arte also gives ateliers for free (Anonymous 2021e). Simultaneously, it is observed a growing number of collectivities of artists as a resilience strategy, a growth that should be followed in the future.

30 Although the reports provided by the professional associations IAC and Consortium of Contemporary Art Galleries lack an academic orientation and methodology, they offer data from the primary source par excellence, the galleries themselves and the professionals who manage them. In addition, the fundamental objective for the preparation of these reports during the pandemic was to offer a realistic vision of the situation the sector was going through, which is why we consider them sufficiently reliable for our analysis.

31 The abrupt closure of galleries in Spain has been referenced in the different reports on the Spanish art market that Dr. McAndrew has published since 2012. While in the 2012 report, an approximate number of 3500 registered art galleries is declared, in the following 2014 report, the number of registered galleries remains at slightly more than 2950, quite lower a figure than the data reflected two years earlier.

The Federal Government is led by the negationist president Jair Bolsonaro. The total of deaths reached 500.000 in June 2020, in the second position after the United States, as well as figured among the 10 countries with the higher percentage of deaths by millions of inhabitants. Art market player, oral communication with the author, São Paulo, 4 June 2021.

In global market reports, these figures are more often estimates, based only on a fraction of the market, and projected to what is supposed to be the market as a whole. We were more interested in indicators to assess variation of business results than in getting an estimate or a fragile global figure.

35 Gallery owner, oral communication with author, São Paulo, 5 December 2020.

36 Gallery owner, oral communication with author, São Paulo, 4 May 2021.

37 This scenario contrasts, in Brazil, with other cultural sectors, such as the performing arts, which have been suffering irreparable losses and whose entrepreneurs and artists may not be able to go through the crisis and continue their activities in a post-pandemic context (Observatório do Itaú Cultural 2020; Fialho 2020). Gallery owner, conversation with the author, 28 May 2020.

Latitude-Platform for Brazilian Art Galleries Abroad, is a project aiming the internationalization of the Brazilian Contemporary Art Market, an initiative by the Brazilian Association of Contemporary Art (ABACT) in partnership with the Brazilian Trade and Investment Promotion Agency (Apex-Brasil), using a combination of private and public funds. For more information: http:/ / www.latitudebrasil.org/sobre-nos/apresentacao/ (accessed on 1 May 2021).

40 Export statistics show consolidated exports for commercial purposes and temporary exports for cultural purposes (participation in exhibitions, for example), so the volume of exports should not be confused with the volume of sales of works of art. In any case, the constant increase in the volume of exports in recent years points unequivocally to a greater international circulation of works of art, partly driven by the movement of art galleries. In 2019, exports surpassed the US $\$ 400$ million mark, according to the Painel de dados do Observatório do Itaú Cultural, data available at: https:/ / www.itaucultural.org.br/observatorio/paineldedados / (accessed on 25 May 2021).

41 It is important to note that this is the average percentage in 2017; for example, for half of the respondent galleries, this percentage reaches $20 \%$, and for a smaller group (eight galleries), $40 \%$ (ABACT/Latitude 2018).

42 In 2020, 23\% of galleries surveyed reported sales to international institutions (in 2014, they were 21\%; in 2017, 29\%). Sales in 2020 were made to the following institutions: Perez Art Museum Miami, National Gallery of Modern Art New Delhi, Guggenheim Abu Dhabi, Contemporary Art Institute Chicago, Fundación Otazu/Spain, die Mobiliar Art Collection/Switzerland, Museum of Modern Art/New York, Dallas Museum of Art, Centre Georges Pompidou, Fundación Atchugarry/Uruguay. It is certainly not a complete list of institutions because some galleries did not respond to the request of information, but nevertheless, the partial information is sufficient to assess that Brazilian galleries keep reaching international institutions.

43 The engagement of artists in the production of digital content led some art market analysts to question the new role of galleries as content producers. The challenge to monetize this kind of content so far suggests that content production will remain a 
promoting activity rather than a new core business for the gallery sector, but this too early to be sure about it. Some galleries are trying to "sell" digital content, workshops and talks, and the majority offer them for free.

44 The engagement of artists in the production of digital content led some art market analysts to question the new role of galleries as content producers. The challenge to monetize this kind of content so far suggests that content production will remain a promoting activity rather than a new core business for the gallery sector, but this too early to be sure about it. Some galleries are trying to "sell" digital content, workshops and talks, and the majority offer them for free.

45 On the contrary, we recall that the global sales of art and antiques reached an estimated $\$ 50.1$ billion in 2020, down $22 \%$ from 2019 (McAndrew 2021, p. 17).

\section{References}

ABACT/Latitude. 2012. Pesquisa Setorial Latitude. O Mercado de Arte Contemporânea no Brasil. São Paulo: Latitude. Available online: http:/ / www.latitudebrasil.org/pesquisa-setorial/ (accessed on 15 May 2021).

ABACT/Latitude. 2013. Pesquisa Setorial Latitude. O Mercado de Arte Contemporânea no Brasil. São Paulo: Latitude. Available online: http:/ / www.latitudebrasil.org/pesquisa-setorial/ (accessed on 15 May 2021).

ABACT/Latitude. 2014. Pesquisa Setorial Latitude. O Mercado de Arte Contemporânea no Brasil. São Paulo: Latitude. Available online: http:/ / www.latitudebrasil.org/pesquisa-setorial/ (accessed on 15 May 2021).

ABACT/Latitude. 2015. Pesquisa Setorial Latitude. O Mercado de Arte Contemporânea no Brasil. São Paulo: Latitude. Available online: http:/ / www.latitudebrasil.org/pesquisa-setorial/ (accessed on 15 May 2021).

ABACT/Latitude. 2016. Pesquisa Setorial Latitude. O Mercado de Arte Contemporânea no Brasil. São Paulo: Latitude. Available online: http:/ / www.latitudebrasil.org/pesquisa-setorial/ (accessed on 15 May 2021).

ABACT/Latitude. 2018. Pesquisa Setorial Latitude. O Mercado de Arte Contemporânea no Brasil. São Paulo: Latitude. Available online: http:/ / www.latitudebrasil.org/pesquisa-setorial/ (accessed on 15 May 2021).

Afonso, Luís Urbano, and Alexandra Fernandes. 2019. Mercados da Arte. Lisboa: Edições Sílado.

Anonymous. 2019. Cluster Art Market and Collection. Available online: https://ihapgmercado.weebly.com/cluster-amc.html (accessed on 28 May 2021).

Anonymous. 2020a. Galerias de Arte Afetadas Expressam Preocupação com os Artistas. Observador, April 6. Available online: https: // observador.pt/2020/04/06/galerias-de-arte-afetadas-expressam-preocupacao-com-os-artistas/ (accessed on 3 May 2021).

Anonymous. 2020b. Artistas e Galerias Enfrentam Pandemia 'Altamente Prejudicial' para o Setor. Observador, November 28. Available online: https:/ / observador.pt/2020/11/28/artistas-e-galerias-enfrentam-pandemia-altamente-prejudicial-para-osetor/ (accessed on 10 May 2021).

Anonymous. 2021a. The Art Newspaper. COVID-19: Witch Countries Are Closest to Getting Back to Art Business? Available online: https:/ / www.theartnewspaper.com/analysis/covid-19-in-the-art-world-a-year-on (accessed on 28 April 2021).

Anonymous. 2021b. Mapa das Artes, Lisboa. Arte Contemporânea. Available online: https:/ / mapadasartes.pt/ (accessed on 11 May 2021).

Anonymous. 2021c. Lay-Off Simplificado-Medidas Excecionais e Temporárias de Resposta à Epidemia Covid-19. Available online: https:/ / www.dgert.gov.pt/covid-19-perguntas-e-respostas-para-trabalhadores-e-empregadores-faq/medidas-excecionaise-temporarias-de-resposta-a-epidemia-covid-19 (accessed on 12 May 2021).

Anonymous. 2021d. Decreto-Lei que Aprova o Estatuto dos Profissionais na Área da Cultura. Available online: https://www. consultalex.gov.pt/ConsultaPublica_Detail.aspx?Consulta_Id=195 (accessed on 17 May 2021).

Anonymous. 2021e. Mercado p'la Arte-A New Art Fair. Umbigo Magazine, April 15. Available online: https://umbigomagazine.com/ en/blog/2021/04/15/mercado-pla-arte-uma-nova-feira-de-arte/ (accessed on 19 May 2021).

Anonymous. 2021f. A AAVP-Associação de Artistas Visuais em Portugal. Available online: https:/ /aavp.weebly.com/ (accessed on 19 May 2021).

Apex-Brasil. 2021. Inteligência de Mercado. Painel de Comércio Brasil—Mundo. Available online: https://paineisdeinteligencia. apexbrasil.com.br/painel-covid-19.html (accessed on 7 July 2021).

Art Dealers Association of America. 2020. U.S. Art Galleries Project 73\% Loss in Second Quarter Revenue Due to COVID-19 Developments. Available online: https:/ / www.artdealers.org/sites/default/files/COVID-19\%20Impact $\% 20$ Survey $\% 20$ of $\% 20$ U.S.\%20Art\%20Galleries\%20-\%20FINAL_1.pdf (accessed on 19 May 2021).

Banks, Mark. 2020. The work of culture. European Journal of Cultural Studies 23: 648-54. [CrossRef]

Becker, Howard S. 2010. Mundos da Arte. Lisboa: Livros Horizonte. First published 1982.

Bourdieu, Pierre. 2011. O Poder Simbólico. Lisboa: Edições, vol. 70, pp. 3-13.

Cardoso, Joana Amaral. 2018. Primeiro Ministro Anuncia Programa a 10 anos para Comprar Arte Portuguesa. Público, October 10. Available online: https:/ / www.publico.pt/2018/10/10/culturaipsilon/noticia/estado-vai-ter-programa-anual-para-comprararte-contemporanea-portuguesa-1847086 (accessed on 13 May 2021).

Comité Professionnel des Galeries d'Art. 2020. Impact de la Crise Sanitaire Covid-19 sur L'économie des Galleries D’art. Available online: http:/ / www.comitedesgaleriesdart.com/sites/default/files/atoms/files / cpga_cp_impact_crise_sanitaire_et_eco_sur_ galeries.pdf (accessed on 18 May 2021).

Comunian, Roberta, and Lauren England. 2020. Creative and cultural work without filters: Covid-19 and exposed precarity in the creative economy. Cultural Trends 29: 112-28. [CrossRef] 
Consorcio de Galerías de Arte Contemporáneo. 2020. Balance Económico de la Repercusión del Covid-19 en las Galerias de Arte Contemporâneo en España. Madrid: Unpublished Internal Document.

Consorcio de Galerías de Arte Contemporáneo. 2021. Informe Sobre el Impacto de la Covid-19 en el Sector de las Galerias de Arte Contemporâneo en España, um año Después de Iniciaerse la Pandemia. Madrid: Unpublished Internal Document.

Duarte, Adelaide. 2020. The Periphery is beautiful. The rise of the Portuguese Contemporary Art Market in the 21st Century. Arts 9: 115. [CrossRef]

Esmanhotto, Mônica, and Ana Letícia Fialho. 2020. Latitude Performance Report of Contemporary Art Galleries during the COVID-19 Pandemic. São Paulo: ABACT/Latitude.

Estatísticas da Cultura, INE. 2019. Inquérito às Galerias de Arte e Outros Espaços de Exposições Temporários. Lisboa: Instituto Nacional de Estatística.

Ferraz, Marcos Grinspum. 2020. Um ano bom, ao Menos para o Mercado de Arte. Arte!Brasileiros, 21 de Dezembro de 2020. Available online: https:/ / artebrasileiros.com.br/arte/reportagem/um-ano-bom-ao-menos-para-o-mercado-de-arte/ (accessed on 22 May 2021).

Fialho, Ana Letícia. 2019. Mercado de Arte Global, Sistema Desigual. São Paulo: Revista do Centro de Pesquisa e Formação, $\mathrm{n}^{\circ} 9$.

Fialho, Ana Letícia. 2020. O iminente Colapso do Setor Cultural. Pandemia Evidencia os Limites das Iniciativas Privadas e Aumenta a Necessidade de Políticas Públicas Para a Cultura. Available online: https:/ / www.select.art.br/o-iminente-colapso-do-setorcultural/ (accessed on 4 May 2021).

Gerlis, Melanie. 2020. Art Market Report Shows the severe Impact of Covid-19. Available online: https://www.ft.com/content/ff653 0b4-1c40-497c-bd23-c5a70e552401 (accessed on 4 May 2021).

IAC. 2020. Informe Sobre el Impacto Económico y Profesional de la Crisis del Covid-19 en Las/os Socias/os del IAC. Available online: https:/ / www.iac.org.es/observatorio/comunicados-informes-acciones-iac/informe-impacto-covid-19.html (accessed on 4 May 2021).

Keh, Pei-Ru. 2021. Frieze New York 2021: The Highlights. Wallpaper, May 5. Available online: https://www.wallpaper.com/art/friezenew-york-2021-preview (accessed on 17 May 2021).

Matos, Sara Antónia, and Pedro Faro. 2021. Flora. Aquisições do Núcleo de Arte Contemporânea da CML e do Atelier-Museu Júlio Pomar (2018-2020). Lisboa: Atelier-Museu Júlio Pomar.

McAndrew, Clare. 2020. The Impact of Covid-19 on the Gallery Sector-A 2020 Mid-Year Survey. Art Basel \& UBS Report. Basel: Art Basel \& UBS.

McAndrew, Clare. 2021. The Art Market 2020. Art Basel \& UBS Report. Basel: Art Basel \& UBS.

Menger, Pierre-Michel. 2012. Être artiste. Oeuvrer dans L'incertitude. Bruxelles: Al Dante/AKA.

Michalska, Julia, and Anna Brady. 2020. Galleries Worldwide Face 70\% Income Crash Due to Coronavirus, Our Survey Reveals. The Art Newspaper. Available online: https:/ / www.theartnewspaper.com/news/galleries-face-70-income-crash-due-to-the-coronavirus (accessed on 15 April 2021).

Ministerio de la Cultura y Deporte. 2020. Anuario de Estadísticas Culturales. Madrid: Ministerio de la Cultura y Deporte. Available online: https: / / www.culturaydeporte.gob.es/dam/jcr:52801035-cc20-496c-8f36-72d09ec6d533/anuario-de-estadisticasculturales-2020.pdf (accessed on 15 April 2021).

Miranda de Almeida, Cristina, and Benjamín Tejerina. 2020. El tercer espacio del arte. In En Riesgo. Diagnósticos, Propuestas y Luchas en Torno a la Precariedad del Arte Contemporáneo. Edited by Concepción Elorza Ibáñez de Gauna and Nerea Ayerbe. Madrid: Dyckinson, pp. 161-73.

Moulin, Raymonde. 1989. Le Marché de la Peinture en France. Paris: Les Éditions de Minuit, pp. 40-41. First published 1967.

Moulin, Raymonde. 2007. Mercado de Arte. Mundialização e Novas Tecnologias. Porto Alegre: Editora Zouk. First published 2003.

Moureau, Nathalie, and Dominique Sagot-Duvauroux. 2006. Le Marché de L'art Contemporain. Paris: La Découverte.

Neves, José Soares (Coord.), Rui Telmo Gomes, and Maria João Lima e Joana Azevedo. 2021a. Inquérito aos Profissionais das Artes e da Cultura: Report\#2 Relações Laborais e Remunerações. Lisboa: Observatório Português das Atividades Culturais, CIES-Iscte.

Neves, José Soares (Coord.), Rui Telmo Gomes, and Maria João Lima e Joana Azevedo. 2021b. Inquérito aos Profissionais das Artes e da Cultura: Report \#3 Enquadramento na Segurança Social e nas Finanças. Lisboa: Observatório Português das Atividades Culturais, CIES-Iscte.

Neves, José Soares. 2020. O sector artístico e cultural, impactos e desafios da crise provocada pela COVID-19, Renato Miguel do Carmo, Inês Tavares, Ana Filipa Cândido (Org.). In Um Olhar Sociológico Sobre a Crise COVID-19 em Livro. Lisboa: Observatório das Desigualdades, pp. 83-96.

Observatório do Itaú Cultural. 2020. Dez anos de Economia da Cultura no Brasil e os Impactos da Covid-19. Available online: https://portal-assets.icnetworks.org/uploads/attachment/file/100687/EconomiadaCulturanoBrasileosImpactosdaCOVID19_PaineldeDados_nov.pdf (accessed on 12 April 2020).

Pérez-Ibáñez, Marta. 2018. El Contexto Profesional y Económico del Artista en España: Resiliencia Ante Nuevos Paradigmas en el Mercado del Arte. Granada: Editorial Universidad de Granada.

Pérez-Ibáñez, Marta. 2020. Artistas, galerías y resiliencia ante la crisis. La génesis de nuevas tendencias y modelos de negocio en el actual mercado español del arte. In En Riesgo. Diagnósticos, Propuestas y Luchas en Torno a la Precariedad del Arte Contemporáneo. Edited by Concepción Elorza Ibáñez de Gauna and Nerea Ayerbe. Madrid: Dyckinson, pp. 175-85. 
Pérez-Ibañez, Marta, and Isidro López-Aparicio. 2018. Art and Resilience: The Artist's Survival in the Spanish Art Market-Analysis from a Global Survey. Sociology and Antropology 6: 221-36. [CrossRef]

Quemin, Alain. 2002. L'Art Contemporain International: Entre les Institutions et le Marché. Le Rapport Disparu. Paris: Éditions Jacqueline Chambon ArtPrice.

Quemin, Alain. 2013a. Les Stars de L'Art Contemporain. Notorieté et Consécration Artistiques dans Les Arts Visuals. Paris: Éditions du CNRS.

Quemin, Alain. 2013b. International Contemporary art Fairs in a 'Globalized' Art Market. In European Societies. London: Routledge.

Quemin, Alain. 2020. Can Contemporary Art Galleries be Ranked? A Sociological Attempt from the Paris Case. In The Sociology of Arts and Markets, Sociology of the Arts. Edited by Andrea Glauser. London: Palgrave Macmillan, pp. 339-62.

Resolução de Conselho de Ministros n 50/2021. 2021. Lisboa: Diário da República n 91/2021, Série I, May 11.

Robertson, Ian. 2018. New Art, New Markets. London: Lund Humphries.

Roque, Mário. 2020a. O mundo Por Estes Dias (O Mercado da Arte e a Covid-19). Available online: https:/ /visao.sapo.pt/exame/ opiniao-exame/2020-03-31-o-mundo-por-estes-dias-o-mercado-de-arte-e-a-covid-19/ (accessed on 5 May 2021).

Roque, Mário. 2020b. De Volta ao Mercado da Arte Com os Modernistas. Available online: https://expresso.pt/opiniao/2020-06-08 -De-volta-ao-mercado-da-arte-com-os-modernistas (accessed on 5 May 2021).

Salema, Isabel. 2020. De Alexandre Estrela a Von Calhau: As Primeiras Compras do Estado com o Novo Fundo Para a Arte Contemporânea. Público, January 8. Available online: https://www.publico.pt/2020/01/08/culturaipsilon/noticia/alexandreestrela-von-calhau-primeiras-compras-estado-novo-fundo-arte-contemporanea-1899675 (accessed on 14 May 2021).

Saltz, Jerry. 2020. The Last Days of the Art World ... and Perhaps the First Days of a New One Life after the Coronavirus Will Be Very Different. Available online: https:/ /www.vulture.com/2020/04/how-the-coronavirus-will-transform-the-art-world.html (accessed on 13 May 2021).

Saltz, Jerry. 2021. Frieze and the Return of the Megafairs. Social Reentry, Sensory Overload, and Some very Good Art at the First Big Event Since ... Well You Know When. Art Review, May 12. Available online: https://www.vulture.com/article/jerry-saltzreview-frieze-2021.html (accessed on 13 May 2021).

Sara and André. 2020a. Inquérito a 471 Artistas. Contemporânea. Available online: https:/ / contemporanea.pt/edicoes/inquerito-471artistas/inquerito-471-artistas (accessed on 17 May 2021).

Sara and André. 2020b. Inquérito a 263 Artistas. Special Issue. Lisboa: Contemporânea.

Schiuma, Giovanni, and Antonio Lerro. 2017. The Business Model Prism: Managing and Innovating Business Models of Arts and Cultural Organisations. Journal of Open Innovation: Technology, Market, and Complexity 3: 1-13. [CrossRef]

St. Aubyn, Miguel. 2020. O Impacto Económico da Pandemia Covid-19 em Portugal. Madrid: Pensamiento Iberoamericano, $\mathrm{n}^{\circ} 9$ (Tercera Época), pp. 42-50.

Sutton, Benjamin. 2021. What sold at Frieze New York 2021? Artsy. Available online: https://www.artsy.net/article/artsy-editorialsold-frieze-new-york-2021 (accessed on 17 May 2021).

Velthuis, Olav, and Stefano Baia Curioni. 2015. Cosmopolitan Canvases. The Globalization of Markets for Contemporary Art. Oxford: Oxford University Press.

Xydas, Fotini. 2020. The Art Market Response to a Global Pandemic. Citi GPS: The Global Art Market and Covid-19. Innovating and Adapting. Available online: https:/ / www.privatebank.citibank.com/newcpb-media/media/documents/insights/Citi-GPSArt-report-Dec2020.pdf (accessed on 25 May 2021).

Zarobell, John. 2017. Art and the Global Economy. Berkeley: University of California Press. 